\title{
Legal Norms and International Economic Development: the Case of the Cuba Shipping Restriction in the United States Foreign Assistance Act
}

\author{
John R. Wilkins*
}

$\mathrm{T}$ HE FOREIGN ASSISTANCE ACT of 1961 prohibits the United States from providing aid to any country which fails to take appropriate steps to prevent ships of its registry from transporting equipment or commodities to Cuba. ${ }^{1}$ Although some countries have objected to this legislation, ${ }^{2}$ none has argued that its application to either existing or

* B.A., 1944, University of Wisconsin; LL.B., 1947, Harvard University; Professor of Law, University of California, Berkeley; formerly General Counsel, United States Agency for International Development. The author is grateful for the financial assistance in preparing this Article provided by a research grant from the International Legal Studies Program of the School of Law, University of Cahforma, Berkeley.

1 The substance of the provision was first enacted as $\$ 107(\mathrm{~b})$ of the Foreign Aid and Related Agencies Appropriation Act, 1963, Pub. L. No. 87-872, 76 Stat. 1165 (1962). It has been repeated in each successive annual Foreign Aid Appropriation Act. Pub. L. No. 88-258, 77 Stat. 859 (1964); Pub. L. No. 88-634, 78 Stat. 1018 (1964); Pub. L. No. 89-273, 79 Stat. 1004 (1965) ; Pub. L. No. 89-691, 80 Stat. 1020 (1966). In addition, beginning in 1963, a similar provision was included in the foreign aid authorizing legislation. Foreign Assistance Act of 1963, Pub. L. No. 88-205, § 301(e), 77 Stat. 386, as amended, 22 U.S.C. § 2370(a) (3) (1964). That version, which continues to be operative, is as follows:

No funds authorized to be made available under this Act ... shall be used to furnish assistance to any country which has failed to take appropriate steps, not later than 60 days after the date of enactment of the Foreign Assistance Act of 1963-

(A) to prevent ships or aircraft under its registry from transporting to Cuba (other than to United States installations in Cuba)-

(i) any items of economic assistance

(ii) any items which are ... arms, ammumition and implements of war ... or items of primary strategic significance used in the production of ... implements of war, or

(iii) any other equipment, materials, or commodities, so long as Cuba is governed by the Castro regime; and (B) to prevent ships or aircraft under its registry from transporting any equipment, nuaterials, or commodities from Cuba . . . so long as Cuba is governed by the Castro regime.

The President has authority to expend funds, up to a designated amount in any one year, without regard to the requirements of most provisions of the Foreign Assistance Act, including the quoted section. 22 U.S.C. 2364(a) (1964). This fact has relevance only in that it gives the United States executive branch an alternative and is a source of embarrassment if the alternative is not used, since countries aided by the United States presumably know of its existence.

2 Ships and aircraft of 19 "non-Communist" countries were found to have visited 
proposed aid programs is illegal under international law. This Article will make such an argument concerning aid provided to promote economic development. ${ }^{3}$

A large group of nations is engaged in transferring resources to other nations in order to promote the recipients' economic development. The two groups of nations have agreed that such development is an essential and common interest. They have also agreed that while some policies further that interest, others clearly disrupt it. This transfer of resources, with an agreement on its necessity and character, can be viewed as creating an international aid community. The Cuba shipping restriction, on the other hand, can be viewed as disrupting this community's essential interests.

This Article argues, therefore, that a community which agrees that certain behavior disrupts its essential interests should pronounce such behavior illegal.

The Article first presents several authoritative descriptions of the aid objectives of both transferor and transferee nations. Only in the context of such descriptions can one evaluate the international aid community and the consequently disruptive character of the Cuba shipping restriction. The legal significance of these descriptive materials is developed in the following three parts. Part I discusses the procedural setting in which

Cuba once or more after October 23, 1962, the effective date of the first Cuba shipping restriction. Of these countries, 14 were found to have taken "appropriate steps" to "halt" such traffic prior to the critical date, February 14, 1964 (60 days after the effective date of the 1963 Foreign Assistance Act, December 16, 1963). The 14 nations were Lebanon, Greece, Norway, Italy, Denmark, Sweden, West Germany, Japan, Turkey, the Netherlands, Panama, Finland, Canada, and Mexico. Of the remaining 5 the United States immediately terminated military aid to Britain, France, and Yugoslavia, where only small training or supply programs were involved. It announced that it would make no new commitments to its substantial programs in Spain and Morocco. N.X. Times, Feb. 19, 1964, at 1, col. 8. The United States ultimately worked out understandings with the last two countries on the basis of which it concluded that they were taking appropriate steps. Hearings on H.R. 10502 (Foreign Assistance Act of 1964) Before the House Comm. on Foreign Affairs, 88th Cong., 2d Sess., pt. 1, at 1, 6 (1963) (statement of Secretary of State Rusk); N.Y.Times, Feb. 20, at 3, col. 2; id., Feb. 23, § 1, at 1, col. 4, 8, col. 1; id., Feb. 26, at 14, col. 4; id., Mar. 1 , § 4, at 3, cols. 1, 4; id., Mar. 7, at 1, col. 1, 4, col. 1 . The fact that most of the countries listed above are relatively developed does not obviate the important issue of principle, so far as the developing nations are concerned, as shown by the proceedings in the United Nations Conference on Trade and Development discussed in text accompanying notes 45-61 infra. Moreover, there may be analogies in other aid contexts. See note 44 infra.

3 The same issues are involved in amendments passed in 1966, essentially identical with the Cuba shipping provision, but dealing with shipments to North Vietnam. Foreign Assistance Act of 1966, Pub. L. No. 89-583, § 301(h)(4), 80 Stat. 805, 22 U.S.C. § 2370(n) (Supp. II, 1965-66). Legislation had been passed in 1965 requiring the President to consider denying assistance in the same circumstances. Foreign Assistance Act of 1965, Pub. L. No. 89-171, § 301 (d) (4), 79 Stat. 659-60. The distinctions among kinds of assistance are spelled out in part I, subpart A, section 2 of this Article. See text accompanying footnotes 15-18. 
the issue of the shipping restriction might arise, since that setting necessarily influences the arguments used. Part II suggests a conceptual framework based on relationships between the behavior and values of any community and its legal pronouncements and concludes that, within such a framework, the Cuba shipping restriction is illegal. The apphication of that framework is illustrated by several opinions of the International Court of Justice. These opinions show the relationship between the Court's vision of an international community and its legal pronouncements. Similar relationships might exist between the objectives of the aid community and the proposed legal conclusion concerning the Cuba shipping restriction. Part III relates the principal conclusion to the doctrine of "unconstitutional conditions" in the United States domestic welfare programs, suggesting "international constitutional" limits on a nation's unilateral ability to condition aid.

A more sweeping argument can be made that a country able to provide assistance is legally obligated to do so if another country needs aid and will use it effectively. ${ }^{4}$ This argument imphes that conditions which interfere with the objectives of development should not be imposed. The growing body of literature in the United States concerning efforts to condition domestic welfare programs supports this argument in emphasizing the degree to which welfare recipients are "entitled" to benefits. ${ }^{5}$ The argument of a legal obligation to give aid will not be pressed here but

4 A developing "principle of capability" was the subject of a provocative paper by Harold Lasswell at the April 1966 meeting of the American Society of International Law. Lasswell stated that:

A principle of capability asserts that, given the common interest in value optimalization on a world scale, every participant is under an obligation to contribute to the development of all, and especially the inost disadvantaged; and that the obligation is positively correlated with available assets.

There is abundant evidence of a movement toward asserting this position. . . .

....

... Is it becoming unthinkable that a Power possessed of capability will refrain from aiding those who are less well off? Can we say that international law is crystalizing expectations that generate an intense set of grievances when the expectations are not met? Do not these grievances find at Ieast partial expression in refusals of cooperation with a Power that withholds assistance, or gives aid ungenerously or hedged with restrictive conditions?

Lasswell, The Relevance of International Law to the Development Process, in ProceEDINGs OF THE AMERICAN SOCIETY OF INTERNATIONAL LAW 1, 4-5 (1966). See also I. BROWNIIE, Prnnciples of Public Internationat Law 227-28 (1966); Feliciano, Comments on "The Relevance of International Law to the Development' Process, in id. at 15 (oral remarks), concerning a "correlative principle of responsibility" of the transferee countries. But see W. Friedrann, The Changmis Structure of International Law 271 (1964) ("There is no legal obligation to extend economic assistance to ... any foreign state."); Johnson, Book Review, 83 L.Q. REv. 461, 463 (1967).

5 See Reich, Individual Rights and Social Welfare: The Emerging Legal Issues, 74 YALE L.J. 1245 (1965); text accompanying notes 130-37 infra. 
one's attitude toward it is likely to affect his attitude toward the argument made in this Article. Those who affirm a duty to provide foreign or domestic aid may be more receptive to limiting the conditions to which such aid can be subjected.

But whether one focuses, as I do, on the illegality of aid conditions or emphasizes the more sweeping duty to aid, it is hoped that this Article will deepen the study of relationships between law and international cominunity imterest in resource sharing for development purposes. ${ }^{\circ}$

\section{AID FACTS AND AID VALUES}

The first step in developing a legal doctrine is to understand the facts to which it apphes. The primary facts of international aid are large international transfers of public resources and the words officially accompanying those transfers. Therefore, after indicating the magnitude of existing aid transfers, I shall discuss im detail two important formulations of aid purposes to discover the international aid community's evaluation of aid conditions. One sucl formulation is the Umited States foreign assistance legislation, ${ }^{7}$ which authorizes the largest and probably most self-conscious development assistance program. ${ }^{8}$ The other formulation is primarily one of aid-receiving nations as expressed by the United Nations Conference on Trade and Development (UNCTAD). ${ }^{\circ}$ It represents current consensus on the transfer of resources to promote development. Brief allusion will be made to more recent, though less comprehensive, formula-

6 The approach reflects the perspective suggested by Falk and Mendlowitz:

The content of international law is difficult to specify with precision because, despite the proliferation and growth of international institutions in recent decades, international society is still a decentralized system. In a decentralized system, stable expectations tend to fix a norm for the behavior of individual states. The violation of these expectations leads to a destabilizing response, and so the presence of these expectations provides a ineasure by which to assess and guide behavior. In this unanner, tacit understandings operate as a source of Iaw, and the task of the legal analyst is to distill their existence from international practice, rather than to provide a techmical justification for their character as law.

2 R. FalK \& S. MENDIOWTTz, StrategY OF WORLD ORDER 2 (1966).

7 Act for International Development, 22 U.S.C. \$§ 2151-2406 (1964).

8 See S. RUBIN, The Conscience of THE Rich Nations 25 (1966). Great Britain's role in the development of the law of the sea suggests that the practice of a single international actor preeminent in a particular area of international conduct might well be decisive in setting standards in that area. M. Kaplan \& N. KatzenbacH, ThE Poluticar Foundations OF INTERNationar LAW 28 (1961). It might be argued that, in aid practice, the United States has the "power" unilaterally to enact aid doctrine for transferor nations.

- Proceednics of the United Nations Conference on Trade and Developament, Geneva, 23 March-16 June 1964, U.N. Doc. E/Conf. 46/141 (1964) [Volume I hercinafter cited as FINAL ACr AND REPORT]. The transferor nations were present but the consensus of the transferees was the outstanding fact. See note 47 infra \& accompanying text. 
tions of the Development Assistance Committee (DAC) and the General Agreements on Tariff and Trade (GATT) - speaking primarily for transferors - and to those of the Organization of American States (OAS)speaking largely for transferees. ${ }^{10}$ These formulations suggest common values concerning aid transfers. Such values, in turn, provide the basis for legal doctrime dealing with the imposition of political conditions, such as the Cuba shipping restrictions, on development assistance.

\section{A. Aid Facts}

\section{The Magnitude of Development Assistance Transfers}

For the purpose of this Article, four points must be made concerning the magnitude of international development assistance: ${ }^{11}$ The amounts transferred are large, although smaller than the needs of the transferees and the capacities of the transferors. ${ }^{12}$ The number of nations engaged in the transfer is large. Tlie major programs are significantly affected by the transferors' desires to promote the economic well-being of the recipients, although short-term self-interest is also a major motivation. ${ }^{13}$ Although the United States transfers the largest amount of money, it devotes a smaller share of its national income to foreign aid than some other countries. ${ }^{14}$

10 See also 1966 Special Conmittee on Principles of International Law concerning Friendly Relations and Co-operation among States, Report, U.N. Doc. A/6230 (1966); note 143 infra.

11 For a recent summary of this effort, see W. Frtedmann, G. KaLmanorf, \& R. Meagher, Internationac Financtal Am 8-38 (1966) [hereinafter cited as International Financial Am].

12 The difficulty of formulating quantitative targets in relation to needs and capacities is referred to in $i d$. at $391-404$.

13 See S. RUBIN, supra note 8; Hearings on H.R. 10502 (Foreign Assistance Act of 1964) Before the House Comm. on Foreign Affairs, 88th Cong., 2d Sess., pt. 5, at 690-91 (1964).

14 The most recent annual review of the Chairman of the Development Assistance Committee (DAC), an informal coordinating organization of the major western aid transferors, shows that the total net flow of bilateral "long term financial resources" to less developed countries during the 3-year period 1962-1964 totalled approximately $\$ 18$ billion. Of this amount, which represents economic rather than military aid the United States supplied approximately $60 \%$. An insignificant portion of the assistance was fumeled through multilateral agencies. W. Thorp, Development Assistance Efrorts and Polictes of the Medibers of the Developarent Assistance Comantitee, 1965 Review 124-25, 138 (1965) (report by the chairman of DAC to the Organization for Economic Cooperation and Development) [hereinafter cited as THORP Report]. See also AgENCY fOR INIERNATIONAL Developadent, Summary Presentation to the Congress: Proposed Economic Assistance Programs FY 1967, at 12 (1966) [hereinafter cited as A.I.D. Assistance Programs FY 1967].

The aggregate figure of $\$ 40.3$ billion for bilateral assistance from the DAC countries for 1956-1964 reflects an increase from a 1956 figure of $\$ 2.9$ billion to a 1964 figure of $\$ 5.5$ billion. THORP REPORT, supra at $12 \%$. Assistance was provided to aid almost every poor nation in 


\section{United States Development Assistance Legislation as an "Aid Fact"}

(a) Development Assistance and Other Assistance Authorizations.Development assistance is only one of several kinds of assistance which the United States provides. The most important other kinds of assistance are: (1) military assistance, provided to permit the transferee country to play a military role which will help strengthen the "security" of the United States; ${ }^{15}$ (2) supporting assistance, provided to "promote political and economic stability"16 and typically used for short-term political purposes; and (3) assistance given primarily for humanitarian purposes, generally in immediate response to disasters like floods and earthquakes. ${ }^{17}$

Whatever its label, the transfer of aid increases the resources of the transferee. ${ }^{18}$ Resources which the transferee might have used to buy the things the aid transfer pays for are thereby freed for other purposes. It can be argued, therefore, that criticism of aid conditions applies to all categories of aid. However, this Article will concentrate on development

the world during the period 1961-1964. See id, at 134-35 (table). The Sino-Soviet bloc countries provided approximately $\$ 1.3$ billion in assistance to nonbloc countries during 1960-1963. THORP REPORT, supra at 42. For data on Sino-Soviet Bloc aid from 1945-1962, see Carnett \& Crawford, The Scope and Distribution of Soviet Economic Aid, in Stafr of Jonnt Economic Conm., 87tre Cong., 24 SEss., DImensions of Soviet Economac Power 474 (Joint Comm. Print printed together with Hearings Before the Joint Economic Contm. 1962). During the same period Soviet aid to Bloc countries totalled $\$ 6.2$ billion. Id.

Disbursements of assistance by DAC countries as a percentage of national income range widely. During 1962-1964 the net disbursements of assistance ranged from $0.70 \%$ to $0.82 \%$ of the Umited States national income; from $1.26 \%$ to $1.76 \%$ of French national income; from $0.61 \%$ to $0.67 \%$ of Umited Kingdom national income; and from $0.58 \%$ to $0.62 \%$ of German national income. When private transfers are included, these figures increase substantially: the United States ranged from $0.96 \%$ to $1.00 \%$; France, from $1.94 \%$ to $2.31 \%$; the United Kingdom, from $0.92 \%$ to $1.09 \%$; and Germany, from $0.77 \%$ to $1.00 \%$. THORP REPORT, supra at 55 . These figures are notable when it is considered that the Umited Nations Conference on Trade and Development proposed one per cent of national income as a target for aggregate transfers, offical and private. FINAI ACT AND REPORT, silpra note 9 , at 44 .

1522 U.S.C. \& 2311 (1964). The legislation requires coordination of military and economic programs. $I d$. $\$ 2382$.

16 Id. § 2241.

17 Compare Id. § 2261 with A.I.D. Assistance Programs FY 1967, supra note 14, at 206-07. No description of the United States aid programs would be complete without reference to the authorizations of the Agricultural Trade and Development Act of 1954, ch. 469, § 2-305, 68 Stat. 545-59, as amended, Food for Peace Act of 1966, 7 U.S.C. §§ 16911736d (Supp. II, 1965-1966). It has authorized, inter alia, sales of United States surplus agricultural commodities which may be paid for in the currencies of the developing nations. Id. § 101, as amended, 7 U.S.C. \& 1701 (Supp. II, 1965-1966). The autliorization permits the United States to use the currencies for economic development grants and loans. Id. $\$ 104$ (e), (g), as amended, 7 U.S.C. \& 1704(f) (Supp. II, 1965-1966). Programs involving the use of these funds for economic development purposes are often the same programs as those requiring dollar funds made available under the Foreign Assistance Act. S. REP. No. 1527, 89th Cong., 2d Sess. (1966).

18 See also E. Mason, Foreign Am and Foreign Poticy 10 (1964). 
assistance, whose purposes and mechanics have been most fully discussed by transferors and transferees of aid.

(b) The Development Assistance Authorization:Text and Policies.The Foreign Assistance Act, the statutory authorization for the United States' development assistance program, declares as its purposes: "to promote the economic development of less developed friendly countries and areas, with emphasis upon assisting long-range plans and programs designed to develop economic resources and increase productive capacities."19 From the perspective of the United States, therefore, development assistance is the transfer of resources to a "friendly" country that needs it. In making such assistance available, the President is required by the statute to consider whether the transferee country can use the aid effectively and is responding to the economic, social, and political needs of all classes of its people. ${ }^{20} \mathrm{He}$ is also to consider the availability of other public or private resources and the possibility of conflicts with the domestic economic interests of the United States. ${ }^{21}$

These statutory provisions should be considered in the context of both the congressional statement of policy and certain restrictions in the legislation which express what the United States believes it is accomphishing with programs of assistance. The statement of policy begins:

It is the sense of Congress that peace depends on wider recognition of the dignity and interdependence of men, and survival of free institutions in the Umited States can best be assured in a world-wide atmosphere of freedom.

The Congress declares it to be a primary necessity, opportunity, and responsibility of the United States, and consistent with its traditions and ideals ... to help make a historic demonstration that economic growth and political democracy can go hand in hand to the end that an enlarged community of free, stable, and self-rehiant countries can reduce world tensions and insecurity. ${ }^{22}$

The statement also affirms the policy of the United States to make assistance available "on a basis of long-range continuity essential to the

1922 U.S.C. § 2161(b) (Supp. II, 1965-1966).

$20 I d$.

21 Id. The Foreign Assistance Act of 1966 added three subparagraphs which amplify but do not change the theme of the language quoted. 80 Stat. 795 (1966). See also 22 U.S.C. \& 2161(f) (1964), which provides:

No assistance shall be furnished under . . . this title for a project unless the President determines that such project will promote the economic development of the requesting country, taking into account the current human and naterial resource requirements of that country and the overall economic developnent of the country, and that such project specifically provides for appropriate participation by private enterprise.

2222 U.S.C. $\S 2151$ (1964). 
creation of an environment in which the energies of the peoples of the world can be devoted to constructive purposes, free of pressure and erosion by the adversaries of freedom."23 Its tenor is, however, also reflected by the provision that: "It is the sense of Congress that in the administration of these funds great attention should be given to those countries which share the view of the United States on the world crisis . . .."24

Thus, the statement of policy, even with its qualifications, accords with the authorizing language in emphasizing the importance of economic development in promoting both economic well-being and pohtical democracy in transferee countries.

(c) Limitations on the Development Assistance Authority.-Limitations on United States development assistance may be grouped into two basic categories. The first category comprises those limitations implicit in the objectives of aid itself or imposed to improve its administration. These himitations are desigued to achieve aid purposes. The second category covers himitations imposed largely to protect economic interest groups or to achieve pohtical purposes unrelated to the quahity of aid programs. Because they originate in interests other than aid, I call these "non-aid" limitations.

(1) Limitations Designed to Achieve Aid Objectives.-Some conditions are imposed on aid to assure the accomplishment of intended development objectives. Thus, before financing the training of teachertrainers in a developing country, aid administrators may require the transferee to devise a program to use the teacher-trainers for training more teachers. Or, if construction of a fertilizer plant is to be financed, aid administrators may require the receiving country to provide or train people to operate it. Without sucl conditions, neither project would advance development. ${ }^{25}$ Recipients rarely complain in principle about this kind of condition, ${ }^{26}$ although they may argue over details and sometimes find the conditions burdensome.

A condition requiring major political changes in the transferee country but defended as essential to effective utilization of the assistance may

23 Id.

$24 I d$. A recent summary prepared by the Library of Congress for Senator Hruska lists the major public studies of the United States foreign aid programs and briefly states some of the conclusions reached. It provides a good reference point for study of Umited States aid objectives. 112 Cong. Rec. 19349 (1966).

25 For further examples see A.I.D. Assistance Programs FY 1967, silpra note 14, at 51.

26 President Frei of Chile recently stated that be believed it to be in the long run interest of his country to receive assistance for carefully tailored projects, rather than in the form of general import assistance. The latter he said resulted in less self-control on the part of his country. Address by Eduardo Frei, Dec. 21, 1966, in 113 Cong. Rec. S567, S570-71 (daily ed. Jan. 19, 1967) (President Frei's speech inserted at the request of Senator Gruening). 
be more controversial. Land and tax reform conditions are the principal examples. ${ }^{27}$ Controversy arises because the conditions frankly interfere with power balances in the transferee country and because they are based on political and social values not completely shared by transferor and transferee alike. Changes of this sort demanded under the rubric of "selfhelp"-an important theme in the Kennedy Administration's initial assessment of foreign aid goals-may be cliallenged on this ground. Nonetheless, conditions requiring reforms reflect a serious judgment based on aid grounds. The entire development community is seeking to understand the relationship between such reforms and development. Lack of consensus may represent uncertainty about the means pursued, not about development goals. Presumably these conditions would not be imposed if a strong argnment could be made that they impede development.

Conditions imposed to improve the quality of aid administration are similar to those designed to achieve aid objectives. The prime example is section 611(a) of the Foreign Assistance Act, ${ }^{28}$ which dates from Congress' effort in 1958 to prevent the premature and misleading commitment of funds to projects not fully planned at the time of commitment. ${ }^{29}$ Section 611(a) was aimed primarily at aid administrators. It principally affected aid transferees in creating some disappointment at certain delays even though they recognized that these conditions miglit have improved projects. $^{30}$

(2) Limitations Designed to Achieve Non-Aid Objectives.-Some aid limitations have "protectionist" or "special interest" purposes. United States small businesses must be notified of aid financing of procurement early enough to permit them to compete effectively for sucl business. ${ }^{31}$ Procurement with aid funds is permitted outside the United States only where it will produce no adverse economic effects within the United

27 "A recent program loan to an Asian country tied disbursement under the loan to that nation's performance on five financial targets: improved budgeting, better foreign exchange management, restraints on inflationary credit, better domestic revenue collection, and increased domestic savings. The parties agreed on specific goals in each field, with loan disbursements based on actual performance in each sector." In the 1963 Bell-Dantas agreement for Brazil, the disbursement of a combined AID, Treasury Department, ExportImport Bank of Washington, and Food for Peace (P.L. 480) loan "package" was tied to "improved performance on stated reforms, including taxation, a reduced budget deficit, and effective monetary control. The Goulart government did not perform, Brazil's economy deteriorated, and the bulk of the U.S. aid was not released." A.I.D. Assistance Programs FY 1967, supra note 14, at 52-53.

2822 U.S.C. \$ 2361 (a) (1964).

20 H.R. REP. No. 1696, 85th Cong., 2d Sess. 51-52 (1958).

30 For example, the problems related to the need for detailed project presentations in the, Sudan program are referred to in International Financial Am, supra note 11, at 216. 3122 U.S.C. § 2352 (1964). 
States. ${ }^{32}$ At least fifty per cent of aid-financed commodities must be shipped on United States flag vessels. ${ }^{33}$

These conditions, like the Cuba shipping restriction, are irrelevant to achieving aid purposes. But they are different because their role of protecting United States domestic economic interests makes them less flammable politically in the transferee country and because this in turn makes them less disruptive of aid goals. Such a difference suffices at present. In order to distinguish this group of provisions from the Cuba shipping provision more carefully, it would be necessary to consider the justifications for both groups of conditions in more detail. United States interests justifying "protectionist" himitations on aid must be compared with interests in the Cuba isolation policies underlying the shipping restriction. In more general terms, the legal resolution of both cases requires weighing the interests of transferors, of transferees, and of the aid comnunity which reflects the values they share. Further exploration of this process as applicable in the present context is made later in discussing the problem of unconstitutional conditions.

There are also "non-aid" limitations designed primarily to achieve political objectives. ${ }^{34}$ For example, section $620(\mathrm{e})$ of the Foreign Assistance Act is clearly intended to affect the behavior of the aid-transferee country. ${ }^{35}$ It requires the suspension of assistance to the government of any country which has expropriated the property of United States citizens while failing within a reasonable time "to take steps" to meet "its obligations under international law" with respect to such expropriation. This provision, a political one intended to compel the expropriating and aidreceiving country to accommodate the United States investor, is defended on broader grounds. A noncompensated expropriation is viewed as an indication that the expropriating country is unwilling to utilize its resources effectively, including among those resources the capacity to attract

$32 I d$. $\$ 2354$ (a). This condition may be defended as one designed to permit the aidtransferor to be able to afford to continue his transfers. It is similar in purpose to those conditions which bave been imposed for balance of payments reasons, althougb it also has similarities to the "protectionist" conditions discussed above, because the interests of particular industries may be paramount. In any event, it is now a common requirement of United States assistance arrangements that funds be made available only for purchases in the United States, even wbere the law does not require the condition.

3346 U.S.C. \$ 1241(b) (1964).

34 I bave not attempted to exhaust all the relevant sections of the Act, altbough hopefully I have dealt with all the types.

3522 U.S.C. $\S 2370$ (e) (1964). An amendment making the principle of this section binding on the United States Executive Director on the Board of Inter-American Development Bank was approved in 1965. 79 Stat. 23 (1965). See also "Hickenlooper Amendment" to Inter-American Development Bank Act, 4 InT'I Legal Materrals 458-60 (1965) (includes reprint of the amendinent and reports of congressional committees and statements by Representative Reuss and Senator Fulbright on the amendment). 
private foreigu investment. ${ }^{36}$ This argument, unlike the case in which the only apparent United States objective is substantially political, is at least related to development problems. Section 620 (c), a similar provision, requires suspension of aid to a transferee who has failed to pay an admitted indebtedness to a United States citizen. ${ }^{37}$

A second group of provisions with essentially political objectives is included within the Act with no serious thought of influencing aid recipients. ${ }^{38}$ Thus, section 620 (a) precludes assistance to $\mathrm{Cuba}^{39}$ and $620(\mathrm{~b})$ similarly prohibits aid to any country "dominated or controlled by the international Communist movement." ${ }^{\prime 40}$ Some of those who voted for these provisions may have thought that a country would be dissuaded from "going Communist" because it feared losing United States aid or even that Cuba might turn from Communism to gain United States aid. Basically, however, the provisions have no special significance because they simply codify pohicies which the aid administrators would almost certainly follow anyway.

A third group of political conditions is illustrated by the Cuba shipping provision. Its purpose is to prevent the apparent anomaly of a country receiving aid from the United States while engaging in conduct seen as harmful to the United States. ${ }^{41}$ The assumption is that the United States

30 See Olmstead, Foreign Aid as an Effective Means of Persuasion, 1964 Proceedings of the AmIerican Soctety of International Law 205. See also Banco Nacional de Cuba v. Sabbatino, 376 U.S. 398, 435 (1964), commented on in Falk, The Complexity of Sabbatino, 58 AMr. J. INT'工 L. 935,936 n.4 (1964).

3722 U.S.C. $\$ 2370$ (c) (1964).

38 For a similar situation concerning the German assistance program, see J. WHITE, Geraran AID 16 (1965): "Non-recognition of East Germany is the invariable political condition of West German aid, and the Federal Government's degree of success in keeping East Germany diploniatically ostracized is put to the German public as a justification of the aid prograninie. . . . These things are inevitable. What is more interesting is the fact that among the recipients of West German aid the conspicuous political string seeins not to have aroused particularly strong resentnent. . . Only if a recipient ... actually recognizes East Germany, sonething that no important recipient of West Gernian aid has done in recent years, is the aid programme likely to be seriously affected. Even this reservation is weakening, as the Federal Government comes to face the probability that it will not be able to hold the line by such means for nuch longer."

3922 U.S.C. \$ 2370 (a) (1964).

$40 I d$. $\S 2370(\mathrm{~b})$. Provisions such as these niay be profitably considered as evidence of the need for Friednann's distinction between an "international law of cooperation," reflecting the imperatives of the limited but cooperatively interdependent world of the "West," on the one hand, and, on the other, an "international law of coexistence" reflecting the tensions and antagonisms of political entities who view their common interests as very limited. The countries excluded hy the provisions referred to are not part of the "cooperative" community. See W. Friedmann, The Changrng Structure of International Law passim (1964).

41 The published reports indicate that application of the statute was less abrupt than the enactnient itself apparently required. Old aid seens to have been continued and new aid provided when the recipients agreed to use their best efforts to prevent Cuba shipping, at 
is making a gift and should see to it that the beneficiary does not harm its interests. Other examples include a similar provision for North Vietnam $^{42}$ and a provision designed to preclude countries from enforcing more extensive claims to territorial waters than those recognized by the United States. ${ }^{43}$ The provisions are political in the sense that they propose policies which the transferee would not otherwise adopt. They are unilaterally determined and irrelevant to the achievement of any shared aid objectives. ${ }^{44}$

(d) Summary.-As an aid fact, United States development assistance legislation is complex and ambivalent. The legislation authorizes a pro-

least when this was the apparent limit of the country's control over its flagship fleet and when these efforts were likely to be effective over time. The legal theory seems to have been that it was permissible to stop the shipments gradually where there were hurdles to doing so abruptly. The critical fact presumably was not the continuing trickle of trade but that the flagships of aid-receiving countries were largely and effectively withdrawn from the Cuba trade. See authorities cited note 2 supra; 110 Cong. REc. 3333-334 (1964) (remarks of Senator McGovern).

But the purpose of this article is not to report that the United States executive departments won the skirmish, nor that there might have been cavil with their pragmatic legal theory. Its purpose is, at least partly, to consider what would have happened if in the dialogue the issue of the condition's legality had been raised.

42 Foreign Assistance Act $\S 301(\mathrm{~h})(4), 22$ U.S.C. \& 2370(n) (Supp. II, 1965-1966).

43 Section $620(0)$ of the Foreign Assistance Act provides that, "In determiming whether or not to furnish assistance ...., consideration shall be given to excluding . . . any country which hereafter seizes, or imposes any penalty or sanction against, any United States fishing vessel on account of its fishing activities in international waters. The provisions of this subsection shall not be applicable in any case governed by international agreement to which the Umited States is a party." 22 U.S.C. \& 2370(0) (Supp. II, 19651966).

44 Conditions applicable to the European recovery programs may be regarded as part of the early stages of the "common law" of aid conditions. They are reviewed in Cardozo, Intervention: Benefaction as Justification, in EsSAYS on INTERVENTION 63 (R. Stanger ed. 1964). Cardozo points out that the participating countries, "which, it must be recalled, included inost of the well-developed and anti-Communist nations of Western Europe," had to agree to support measures many of which were at least as offensive to "national sovereignty" as those now inposed on the developing countries. Id. at 73-74. Such measures included obligations to stabilize currency, balance their governmental budgets, reduce barriers to trade, and submit to international adjudication any case involving compensation for ineasures affecting property rights of United States nationals. Economic Cooperation Act of 1948, ch. 169, § 115(b), 62 Stat. 150. See also Surrey, The Economic Cooperation Act of 1948, 36 CALIF. L. REv. 509, 514-18 (1948).

Cardozo draws distinctions between conditions based on aid and non-aid purposes and suggests that the joint interest in aid purposes makes aid agreements voluntary but that there unay be a question of improper coercion when non-aid, "unilaterally determined" purposes are involved. See Cordozo, supra at 79-83.

Nor should the Mutual Defense Assistance Control Act, 22 U.S.C. §§ 1611-1613d (1964), popularly known as the Battle Act, be ignored. That Act reqnires the termination of all assistance to any country which permitted itenrs of strategic significance, as defined in the Act or determined by the Act's administrator, to be shipped to any "nation or combination of nations threatening the security of the United States." Id. \& 1611. The application of that Act raises inost of the issues involved here. 
gram and states reasons for the program. At the same time, it attempts to achieve contradictory purposes, by establishing special interest "payoffs" and using political conditions to accomplisl unilaterally determined foreign policy objectives. Any proposal for international legal norms applicable to development aid must deal with conflicts arising from these ambivalent goals of the major transferor of aid and establish some order of priority among them. One way is to turn from a unilateral and domestic document to the international context to see what the United States and other nations have said about aid goals. It is relevant of course that the Umited States domestic document has had an international audience and, as we shall see in considering its self-help emphasis, even an echo.

\section{The United Nations Conference on Trade and Development as an "Aid Fact"}

In 1962 the United Nations passed a resolution designating the 1960's as the United Nations Development Decade. ${ }^{45}$ This resolution was the first in a series which resulted in the United Nations Conference on Trade and Development (UNCTAD). These resolutions reflected the judgment that economic development was essential to the economic and political well-being of the United Nations community and that development was inseparable from the problem of international trading relationships-more particularly, the amounts and kinds of goods sold by the poor nations to the rich and the prices paid for them. ${ }^{46}$ The key pohtical fact of the Conference, in which some one hundred ten nations participated, was the surprising and consistent unanimity of developing nations on the trade and aid issues explored. ${ }^{47}$

The Conference agreed on a series of propositions. There is an international community whose existence is manifested by the existence of the United Nations and by convocation of the Conference. This community is particularly concerned with sharp disparities of wealth among its members. These disparities, im frustrating aspirations and provoking irrationalities ${ }^{48}$ among its members, jeopardize the communty's continued existence. The jeopardy to rich members of the community is perhaps greater than to the poor, since the rich have more at stake in the community's continuation in roughly its present form.

\footnotetext{
45 G.A. Res. 1710, 16 U.N. Supp. 17, at 17, U.N. Doc. A/5100 (1962).

46 See Final ACr AND REPORT, supra note 9, at 3-4 (preamble).

47 See the "Joint Declaration of the Seventy-Seven Developing Countries Made at the Conclusion of the United Nations Conference on Trade and Development," which characterized the "unity of the seventy-five" as "the outstanding feature of the entire Conference and an event of historic significance." FINAI ACT AND REPORT, supra note 9, at 66-67.

48 The last three words express my own projection more than do the other words. I hope it will be clear from all that appears below that it is a fair projection.
} 
It is therefore essential that both rich and poor work toward the increased well-being of the community's membership. This goal is an affirmative one, not calculated merely to stave off disaster. Increased wellbeing will result from a substantial increase in the income of poor nations. One important way of effecting this increase is the sensible use of external assistance-foreign aid-to develop physical and human resources. Another way is to create trading arrangements which permit poor nations to earn their way by selling what they can produce. The two policies are inextricably related. The rich countries should assume an obligation to do everything reasonably necessary to effect aid and trade relationships required to achieve this end. The poor nations in turn should do everything necessary to maximize effective utilization of newly available resources. Although proper conditions may be imposed on aid and trade relationships, conditions which are unilaterally determined, irrelevant, and pohitically exacerbative should be proscribed.

The UNCTAD fornulations on which these conclusions are based are discussed in further detail because their comprehensiveness is relevant to their value as a preface to law norms. After review of these formulations, reference will be made to some more recent documents on the aid problem. On the basis of all these formulations, including previously detailed United States legislation, an effort will be made to develop an authoritative composite of values and in turn to consider the possibility of building legal doctrine on the basis of these values.

The formal results of the Conference are expressed in a Final Act. ${ }^{40}$ The background section of the preamble to the Act states that:

[R] ealizing the dangers of a widening gulf in living standards between peoples, and convinced of the benefits of international co-operation with a view to helping the developing countries to reacl a ligher standard of life, the States signatories of this Final Act are resolved, in a sense of human solidarity, "to employ international machinery for the promotion of the economic and social advancement of all peoples." "50

The preamble was approved without dissent. ${ }^{51}$ The remaining portions of the report were generally subject to divided votes, in which the transferor countries were generally in the minority.

The report stated that all countries agree to pursue economic policies designed to promote a rate of growth in developing countries which will bring a substantial and steady increase in average income, thus narrowing the gap in hiving standards between developing and developed coun-

49 FINAT ACT AND REPORT, supra note 9.

50 Id. at 3, quoting UN. CEARTER preamble.

51 Id. at 111. 
tries. $^{52}$ In addition, an increasing net flow of all kinds of assistance should be provided to developing countries to reinforce their own efforts at economic growth. "Such assistance should not be subject to any political or military conditions." Loans should be provided on generous terms, distributed according to relative urgency of needs. ${ }^{\text {54 }}$

The Conference adopted several annexes which illustrate the cliaracter of some of its concepts, assumptions, and values in respect of development problems. One of these, entitled, "Guidelines for International Fimancial Co-operation," emphasizes, among other things, continuity of assistance from grantors; well developed plans and implementation procedures in transferee countries, including domestic reform designed to make assistance effective; and minimization of "the administrative requirements and formal procedures so as to facilitate the negotiations ... and make possible the timely use of ... assistance."

A second, entitled "Growth and Aid," recognizes that the original growth target of five per cent per annum for the United Nations Development Decade may very well be inadequate and recommends that transferor countries supply resources to developing countries in amounts approximating one per cent of national income. ${ }^{56}$ This is a position which has since been formally accepted as a joint goal by the major transferors of aid. ${ }^{57}$

52 Id. at 18-19 (General Principle Four). The United States voted alone against the text. The abstainers included Canada, the Federal Republic of Germany, France, Japan, and the United Kingdom. Throughout these notes I sball indicate the positions of these countries, as major aid transferors. For evolution of doctrine in this area, compare the United States' negative vote here with its act in joining the sponsors of the language quoted below:

3. In order to make this co-operation fully effective, each Member should, inter alia:

(b) formulate its economic policy and its policy in respect of any economic assistance which it gives or receives, so as to contribute to the acceleration of economic growtl and the equitable elevation of standards of living throughout the world and the economic and social progress and development of other States, and so as to ensure the prudent and efficient use of economic means available to it ...

1966 Special Committee on Principles of International Law concerning Friendly Relations and Co-operation among states, Report, U.N. Doc. A/6230, at 184-85 (1966).

53 FINAI ACT ANd Report supra note 9, at 21 (General Principle Eleven). Negative votes were cast by Australia, the Federal Republic of Germany, South Africa, the United Kingdom, and the United States. The abstainers mcluded Canada, France, and Japan.

54 Id. at 24 (Special Principle Eleven). The abstainers included Canada, the Federal Republic of Germany, France, Japan, the United Kingdom, and the United States.

55 Id. at 42-43 (Annex A.IV.I). France and Japan made comments concerning their votes on these guidelines which apparently do not qualify the paragraphs of the Annex paraphrased in the text. $I d$. at $73,76$.

56 Id. at 43-44 (Annex A.IV.2).

57 See text accompanying note 63 infra. 
Considerations recited in connection with a third annex emphasize strengthening the economic and political independence of developing countries, supplementing the efforts made by the countries themselves. Assistance should not be subject to "any political, economic, military or other conditions unacceptable to the developing countries."

Finally, the Conference adopted an "institutional arrangements" annex which, more than any other, reflects the essential character of the international aid community. This annex, adopted without dissent, ${ }^{50}$ concerns a whole gamut of institutional arrangements. It includes provisions for the establishment of a committee to develop conciliation procedures "to take place before voting and to provide an adequate basis for the adoption of recommendations . . . of a specific nature for action substantially affecting the economic or financial interests of particular countries. ${ }^{300}$ The participants at UNCTAD, including those who were voted down on particular issues, all wanted to remain part of UNCTAD. They did not want UNCTAD to reach conclusions which might adversely affect their interests and perhaps drive them out of the UNCTAD community without giving them prior opportumity to express their objections fully. ${ }^{01}$

\section{DAC, GATT, and OAS: "Aid Facts" Since UNCTAD}

Although UNCTAD included more countries than any other conference on aid matters, its basic policies had been expressed by earlier and less comprehensive groups. The predecessor of the Development Assistance Committee (DAC), an organization of major aid transferors, lad resolved in 1961 that because the less developed countries needed help in improving their living standards, the transferor members should make increased and more effective aid available to them. Aid should be assured on a continuing basis, and aid programs would be periodically reviewed, "keeping in mind all the economic and other factors that may assist or impede ... in helping to achieve the common objective." nations themselves thus unequivocally asserted long before UNCTAD that an effective assistance effort was essential.

In July 1965, DAC members responded to the new initiative represented by UNCTAD by resolving to take steps to implement certain

58 Final ACT AND RePort, supra note 9, at 44 (Annex A.IV.3).

$59 I d$. at 58 n.87.88 (Annex A.V.1.).

60 Id. at 60 .

61 For a report on some of the results, see Proposals for a Process of Conciliation Within U.N. Conference on Trade and Development, U.N. Doc. A/5749 (1964), in 4 INT't Legal Materiats 51 (1965). See also U. KIRdar, The Structure of United Nations ECONOMHC ATD TO UNDERDEVEIOPED COUNTRIES 256-57 (1966).

02 Development Assistance Group Concludes Fourth Meeting, 44 DeP'T State Butr. 553, 554-55 (1961) (text of Resolution on Common Aid Effort printed in full). 
policies. These included attaining or exceeding the UNCTAD target of one per cent of national income for assistance, giving assistance to those countries making the inost effective use of their resources, and encouraging continuing efforts at development by indicating willingness to provide continued support. ${ }^{63}$ This resolution is substantially similar to statements adopted by UNCTAD in its appraisal of the development assistance problem. It stresses the urgency of the problem and the consequent need for the "rich" nations to act. The political conditions issue-whicl liad been explicitly addressed by UNCTAD-was evidently viewed as either irrelevant or too difficult to handle. The issue may have been avoided because the transferor nations could not resolve the inconsistency between their own recognition of the urgency of developinent goals and the potential impact which such conditions would have on achieving those goals.

The General Agreements on Tariff and Trade (GATT) was formed to resolve trading problems of the industrially developed transferor countries and is even now dominated by them, althougln developing countries are in the majority. ${ }^{64}$ However, GATT recognizes that the developed members' interests are interdependent with the interests of developing member and nonmember countries.

GATT also responded to the UNCTAD inpetus in 1965 when the GATT contracting parties signed a protocol amending GATT by introducing a new "Trade and Development" provision. ${ }^{65}$ The parties recognized the importance of raising standards of living in less developed countries by ensuring them a share in growing international trade and stated that developed countries would not expect reciprocity in lowering barriers to the trade of less developed contracting parties. ${ }^{66}$ GATT has thus recognized the urgency of development, the interdependent interests of members of the overlapping trade and aid communities involved, and the actions which must be taken to serve these common interests.

These same themes appear in recent proceedings in the Organization of American States (OAS). A preliminary statement on charter revision, in which the United States joined, was issued in November 1965 stating that the economic aspect of the inter-American system should include juridically binding principles of mutual assistance. Amendments were also to be prepared stating that the member states accepted the "obligation" of providing assistance to less developed countries and that they agreed

63 THORP REPORT, supra note 14, at 115-16.

64 On the role of the developing nations in GATT, see Meier, UNCTAD Proposals for International Economic Reform, 19 STAN. L. REv. 1173, 1178-85 (1967).

65 General agreescent on Tarifrs and Trade, Bastc Instruments and Selected Docuntents 1 (13th Supp. 1965).

66 Id. at $2-4$. 
to avoid measures that might endanger the economic and social development of other member states. ${ }^{67}$ These sweeping statements were later negotiated down to the Protocol of Amendment signed on February 27, 1967. The language of "obligation" became the bland agreement "to cooperate with one another, in the broadest spirit of inter-American solidarity, as far as their resources may permit and their laws may provide." ${ }^{\circ 8}$ Even as finally agreed upon, however, the amendments represent one more step in the international aid community's commitment to the importance of aid and to ensuring its effectiveness. ${ }^{69}$

6753 Dep't State BULI. 998-1000 (1965). The text was presented on March 17, 1966, to the House Foreign Affairs Committee by Secretary Rusk who stated, "The leaders of the hemisphere demonstrated their commitment to progress by adopting the Economic and Social Act of Rio de Janeiro last November. This act added an important new element to the Alliance: a commitment by all members of the Alliance to help one another and to provide assistance to achieve economic and social objectives set forth in the act." Hearings on H.R. 12445 and 12450 Before the House Comm. on Foreign Affairs, 89th Cong., 2d Sess., pt. 1, at 51 (1966).

In the United Nations, the Special Committee on Principles of International Law Concerning Friendly Relations and Co-operation among States, the United Arab Republic has proposed that there be affirmance of the obligations on the part of economically advanced countries to do what they can to narrow the gap between themselves and the less developed countries. UN. Doc. A/5746 (1964), in 4 InternationaI Legar Materiats 28, 48 (1965). Moreover, Article 2, section 1, of the International Covenant on Economic, Social and Cultural Rights, UN. Doc. A/2200 (1966), reprinted in 56 Dep'T OF StATE BULL. 107 (1967), which uses language respecting the undertaking of economic assistance which the United States feared might be construed to impose a legal obligation to give such assistance. See 56 DEP'T OF StaTe BuxI. 104-07 (1967) (statement by U.S. Alternate Representative Patrica R. Harris).

686 INT'x Legar Materdats 310, 315 (1967) (full text of the Protocol reproduced). Some of the reasons for the apparent shift in the United States position may be discerned from a report in the N.Y. Times. At a meeting in Rio de Janeiro in November 1965, it was decided to modernize the OAS Charter. The United States State Department apparently expected that the subsequent meeting would involve translating the Rio guidelines into general treaty provisions. Instead, there was a Latin American attempt to include specific economic policies binding on the United States in the draft treaty. There were no formal votes on the draft, but the leader of the Washington delegation, Robert Woodward, was assured it could be amended up until signature of the final draft. "Two days later Mr. Woodward exploded a bomb during a meeting of heads of delegations. He said the United States could not accept the draft and that the matter was one for discussion at . . 'ministerial level.' $\mathrm{He}$ was acting on instructions from the State Department. . . . It was called a serious blow to hemispheric unity and doubts were expressed about United States willingness to help Latin America." N.Y. Times, March 27, 1966, § 1, at 7, col. 1. See also id., May 5, 1966, at 15, col. 1; id., June 20, 1966, at 4, col. 5 .

60 An interesting evolution $\mathrm{m}$ aid technique is the movement toward increased use of international institutions as funnels for United States aid transfers. See 22 U.S.C. $\$ 2221$ (a) (1964). A compromise between the technique of a transfer of funds to an international organization and carrying out a purely bilateral prograin is the practice in the latter case of relying on the economic judgments of "neutrals" such as the International Bank for Reconstruction and Development (the "World Bank"). Recent steps in this direction are described in N.Y. Times, April 13, 1966, at 11, col. 1. This is similar to the use of the "Nine 


\section{B. Aid Values}

There are two ways of describing aid values as a preface to the development of aid doctrine. First, one can determine areas of consensus between transferor and transferee nations. These areas of consensus are reflected for the transferee nations in the UNCTAD formulations and for the United States in its affirmative votes in UNCTAD and other international forums and in the text of its Foreign Assistance Act. Second, one can base aid values on "insistent themes" in the transferor's vocabulary-the repeated phrases and ideas with their accompanying actswhich reveal the dominant values of the transferors.

\section{Areas of Consensus}

The description of aid values based on consensus will focus on three areas: conceptions of "international community," conceptions of the relationship between economic aid and the interests of that community, and conceptions of appropriate limitations on resource transfers.

(a) Conceptions of "International Community."-It is the official position of the United States that "peace depends on wider recognition of the dignity and the interdependence of men"; that the survival of its own free institutions depends on a "worldwide atmosphere of freedom"; that assistance has been provided in the past and continues to be necessary "to help make a historic demonstration that economic growth and political democracy can go hand in hand to the end that an enlarged community of free, stable, and self-reliant countries can reduce world tensions and insecurity."70 Such statements are based on the conviction that the United States is inextricably involved in a world community, and that it can protect its own role and values in that community only by allowing it to share those values, especially those promoted by international aid. This is not a normative legal proposition. It is a proposition about the realities and interdependence of a world community.

The UNCTAD preamble, in which the United States concurred, reflects similar value judgments. The position is effectively echoed in DAC's formal endorsement of the UNCTAD recommendation of a one per cent development assistance self-levy on developed countries ${ }^{71}$ and in GATT's endorsement of tariff preferences for the poor nations, with no expectation

Wise Men" and later the Committee for Inter-American Progress (CIAP) as independent entities to evaluate Latin American aid projects. The progenitor in a very different context was the Organization for European Economic Cooperation (OEEC) which took a central role in Marshall Plan decision making. The effort in each case is to substitute "neutral" judgment for bilateral and therefore less neutral pressures.

70 Act for International Development § 102, 22 U.S.C. § 2151 (Supp. II, 1966).

71 See text accompanying note 63 supra. 
of reciprocity. ${ }^{72}$ There is no significant disagreement between the United States and the UNCTAD majority over the interdependence of the interests of the rich and poor nations of the world or the dangers of continued disparities in wealth, especially when coupled with growing political awareness of that disparity. ${ }^{73}$ These data disclose common interests which, in turn, define a meaningful international community. ${ }^{74}$

(b) Conceptions of the Role of Aid in Relation to the Interests of the International Community.-Edward S. Mason, a distingnished American economist who has had much to do with the formation of United States aid policy, has said that a foreign aid program should be based on the facts that aid can effectively contribute to the economic development of the less developed world and that most countries desperately want to be independent of external control. "The link between these two facts is provided by a proposition for which there is substantial evidence, namely that favorable prospects for economic development have significant relevance for the ability of countries to maintain their independence." ${ }^{\prime \prime 5}$ This

72 See text accompanying notes 65-66 supra. Nor should one forget in context articles 55 and 56 of the United Nations Charter:

"Art. 55. With a view to the creation of conditions of stability and well-being which are necessary for peaceful and friendly relations among nations based on respect for the principle of equal rights and self-determination of peoples, the United Nations shall promote:

a. higher standards of hiving, full employment, and conditions of economic and social progress and development;

b. solutions of international economic, social, health, and related problems ....

....

Art. 56. All Members pledge themselves to take joint and separate action in cooperation with the Organization for the achievement of the purposes set forth in Article 55.

These provisions were not conceived and are not cited as representing a legally binding commitment of particular specificity. However, the statements do represent a value consensus emphasizing again the importance to the international community of economic problems and of cooperating to achieve their solutions.

73 See note 97 infra.

74 This article does not examine the question whether Umited Nations resolutions constitute law. United Nations resolutions, recommendations, and policy statements are cited here primarily to show a value consensus, and no attempt has been made to distinguish sharply the precise "label" on these documents. For early statements on the legal status of United Nations actions, see Johnson, The Effect of Resolutions of the General Assembly of the United Nations, 32 BRTr. Y.B. INT'x L. 97 (1955-56); Sloan, The Binding Force of a 'Recommendation' of the General Assembly of the United Nations, 25 BRIr. Y.B. INT'L L. 1 (1948). For more recent statements, see Dugard, The Legal Effect of United Nations Resolntions on Apartheid, 83 S. AFr. L.J. 44 (1966); Falk, On the Quasi-Legislative Competence of the General Assembly, 60 Axr. J. INT'x I. 782 (1966); Lande, The Effect of the Resolutions of the United Nations General Assembly, 19 WorLd PoLITICs 83 (1966). See generally Landis' classic piece Statutes and the Sources of Law, in Harvard Legar Essays 213 (1934).

75 E. Mason, Foreign Am and Foretgn Poltcy 50-51 (1964). Cf. J. Pnncus, Economic Am and Cost SHaring 48-49 (1965): "Ultimately, . . . the case for such a policy [aid] 
judgment is in accord with the policy of the Foreign Assistance Act that a major purpose of our programs is the creation of "an enlarged community of free, stable, and self-reliant countries." ${ }^{.76}$ The belief that aid transfers can eventually be terminated is based on the premise that those transfers build self-sustaining forces for growth which are also likely to promote independence. Countries cited as examples of successful United States aid programs are usually those which have become economically stable and politically independent. The clear implication is that the two are corollaries.

Even the aid-relevant limitations on aid transfers can be better understood from the perspective of promoting political independence. Limitations which require planning, for example, are designed to prevent the wasting of resources through mismanagement of aid. The most serious consequence of sucl mismanagement is the embarrassment of the political leadership identified with it. In developing nations whose governments have only precarious political control, such embarrassments often discredit the only people interested in promoting both development and political independence. Ineffective aid may thus frustrate the effort to demonstrate "that economic growth and political democracy can go hand in hand." $" 77$

There is no dissent from these propositions in the vocabulary of poor nations. The transferee nations recognize that they must plan and reform to make assistance effective, ${ }^{78}$ even though this involves consultation which could be regarded as an infringement of prerogatives of politically independent entities. ${ }^{79}$

(c) Conceptions of Relevant, Irrelevant and Bad Limitations on Aid Transfers.-Aid transferors and transferees generally agree on basic aid conditions. Almost all the UNCTAD provisions quoted, the United States assistance provisions concerning what the President should "consider," the provisions from DAC, GATT, and the OAS (both versions), and the bulk of the burgeoning literature on aid and the necessity of self-help reflect a consensus that some conditions are needed to make aid

rests on the justification that economic growth promotes the development of free societiesor at least independent ones; and that Western values are more likely to prosper in such an atmosphere."

7622 U.S.C. \& 2151 (Supp. II, 1965-1966).

7722 U.S.C. \& 2151 (Supp. II, 1965-1966).

${ }^{78}$ See generally Feliciano, Comments on "The Relevance of International Law to the Development Process," in Proceedings of the American Society of Internationar Law 15-17 (1966) (oral remarks).

79 See FnNax ACT AND REPORT, supra note 9, at 18 (General Principle One): "Economic relations between countries, including trade relations, shall be based on respect for the principle of sovereign equality of States, self-determination of peoples, and non-interference in the internal affairs of other countries." 
effective. Political conditions, on the other hand, are decried but regarded as inevitable. ${ }^{80}$

Despite this resignation, the necessity for political conditions should be judged by looking at the character of inquiries made into the effectiveness of aid. The wide range of policy and administrative judgments reflected in the UNCTAD conclusions indicate what kinds of conditions are relevant for promoting effective aid. ${ }^{81}$ By reference to those conditions the Cuba shipping condition is irrelevant. Irrelevant conditions should be proscribed because they exhaust scarce energies in the developing country when those energies are needed to cope with the already formidable barriers to development. The Cuba shipping provision, then, should be proscribed-on policy grounds-because it is irrelevant.

An aid condition should also be proscribed when it interferes with the transferee's normal expectation of determining for itself those international policies unrelated to development. In the case of the Cuba shipping restriction the political question is whether the transferee's flagship fleet should participate in the economic quarantine of Cuba. A third country's attempt, however justified, to interfere with this decision by methods other than persuasion is likely to be inflammatory. The attempt evokes words-like "sovereignty," "intervention," and "coercion"82_ which suggest sensitive areas of high emotional-political content. Such interference is likely to be more inflammatory when there is no international consensus that the condition is related to development assistance ${ }^{83}$ and when most transferees agree that it is unrelated.

The test may be formulated as suggested above: It is unsound to impose conditions which are irrelevant, unilaterally determined, and politically exacerbative. Under this formulation, the Cuba shipping provision itself is unsound.

80 See 112 ConG. REC. 15334 (daily ed. July 18, 1966) (remarks of Senator Fulbright concerning addition of the North Vietnam shipping provision to the Foreign Assistance Act of 1966).

${ }^{81}$ See text accompanying notes $52-58$ supra. For an extended treatment of the principal problems in aid in connection with each of selected aid receiving countries, see INTERNATIONAL FIVANCIAI AID, supra note 11 , at 152-258. For similar treatment in connection with particular projects and programs, see id. 259-377. These pages reveal the kinds of critiques which the lawyers and economists who focus on the development process think it important to detail in discussing the achievement of development objectives. See also id. 408-412.

82 See text accompanying notes 120-23 infra.

83 With respect to the Cuba shipping provision, there is some consensus concerning Cuba's "bad" behavior and therefore it could be argued that the actions of the United States are not properly characterized as "unilaterally determined." Consensus on Cuba's political behavior does not, however, imply a consensus that the aid program should be used to "police" that behavior. Hopefully, this article will convince readers that the issues at stake should be resolved by broader elements of the aid community than one or several transferors. 


\section{The Insistent Theme of Self-Help}

The second approach to aid values and their impact on the Cuba shipping provision emphasizes the vocabulary of self-help used by aid transferors and their success in causing the transferees to respect the idea. According to the idea of self-help, a dominant theme of the United States development assistance effort, ${ }^{84}$ the transferee country must first examine its problems jointly with the transferor, and then take the measures necessary on its part to make external aid effective. Self-help conditions demanded by the United States have involved, for example, budgeting reform, exchange control, and tax and land reform. ${ }^{85}$ As these examples suggest, self-help is likely to involve substantial political and economic changes in the transferee country, requiring the use of precious political capital by those managing such countries. The notion of self-help for those asked to undertake such steps must therefore imply that if the effort is made, the aid will be forthcoming. It certainly implies that aid will not be rejected for reasons unrelated to the adequacy of the selfhelp. Inducing self-help efforts and relying on their results is inconsistent with the imposition of irrelevant, unilaterally determined, and politically exacerbative conditions. The United States, officially, does not acknowledge this inconsistency. But its vocabulary of self-help simply cannot be otherwise understood.

II

THE PROCEDURAL FRAMEWORK

The next problem is to determine whether the aid values examined can be translated into legal doctrine for dealing with the Cuba shipping restrictions. There are three contexts in which the legality of the Cuba shipping provisions or similar "political conditions" is likely to become an issue.

First, termination of an existing arrangement may be proposed because the United States executive branch, by the terms of the aid legislation, has lost the power to continue it. ${ }^{86}$ If the Umited States has unequivocally agreed to provide some assistance but has not yet provided all of it, serious questions would arise concerning its power under international law to abrogate the agreement. Such questions could not

84 In my judgment, it is impossible to exaggerate the pervasiveness of this theme in the United States aid vocabulary. This theme is the more important because domestically it has required a careful distinction between "national economic planning" and "socialism." See INTERNATIONAI FINANCIAL Am, supra note 11, at 50-51.

85 See notes 25-27 supra and accompanying text.

86 However, the President does have authority to waive application of legislation imposing restrictions on aid. See 22 U.S.C. $\$ 2364$ (a) (1964). 
be resolved simply by referring to equivocal expressions of congressional intent which might be read to require such abrogation. True, provisions in various United States aid agreements often authorize the United States to terminate its disbursements, even for partially completed projects and programs. Since the Marshall Plan period, United States commodity assistance arrangements have commonly included provisions allowing the United States, before unloading an aid shipment in the transferee country, to redirect the shipment, take title in itself, and require officials of the transferee country to confirm the redirection. ${ }^{87}$ Projects granting the services of United States technicians, and commodities in connection therewith, often provide that the agreement is terminable on thirty days' notice. ${ }^{88}$ Finally, development loan agreements normally provide that disbursements may be terminated at any time if they would be "in violation of the legislation governing" the aid program. ${ }^{80}$ Given such provisions, United States aid officials have at least a prima facie basis for asserting a right to cut off aid in the "pipeline" at any time prior to delivery, on relatively short notice.

On the other hand, there are arrangements in which the United States has not reserved a cutoff right. Also, the general language of those agreements which refer to "legislation affecting the right of the [aid agency] to continue disbursements" may beg the question concerning the intent of congressional enactments applicable to "pipeline"; it seems possible to interpret that language as reflecting no intent to cut off aid already committed. Finally it may be argued that, even in the face of the transferee's agreement, the condition is not enforceable under international law.

A second and more likely context in which the legality of the political condition might be questioned would be in negotiations prior to the signature of an aid agreement; the proposed transferee would argue that the United States could not legally compel the condition. Most of the argument in this Article will be based on the assumption that the "suit" would not be to obtain a formal legal ruling but rather to strengthen the hand of the aid-recipient in negotiating a rejection of the limitation. In such a

8722 C.F.R. $\$ \S 201.43-.44$ (1967) (current regulations in effect since 1964).

88 See A.I.D. Manual Order No. 1333.1, Annex B, para. P (effective Jan. 18, 1966) (not published; available on request from the Agency for International Development). Manual orders are internal directives which instruct agency personnel in the carrying out of their duties. Annex $B$ is a list of standard provisions to be used in project agreements which includes in paragraph $\mathbf{P}$ the 30 days' notice provision.

80 See A.I.D. Manual Circular No. 1262.1, Attachment A, art. 8, § 8.03(c) (effective July 7, 1966) ("Standard Provisions for AID Loan Agreements for Capital Projects with Governments"), codified in A.I.D. Manual Order No. 1262.1 as of Dec. 31, 1966 (not published; available upon request from the Agency for International Development, Washington, D.C.). 
context, the United States might well want to respond in a more than perfunctory manner. Most "international law," mucl of it of high quality, is developed in such exchanges.

There is, however, a third and potentially more important context for raising our question. Because there is safety and power in numbers, it is not surprising that the most exphicit resistence to political conditions has occurred in the United Nations. Large majorities in the United Nations Conference on Trade and Development stated twice that political conditions should not be attached to aid. ${ }^{90}$ Neither the United States nor any other transferor country supported these views, ${ }^{91}$ but the views of the transferee countries were clear enough. Althougl the UNCTAD majority did not attempt to plirase its views as legal norms, it certainly affirmed them as unequivocal norms of appropriate aid arrangements.

UNCTAD will probably continue to be a forum for conflict over political conditions, and it seems likely that the issue will eventually be pressed there in conjunction with the question of the transferors' obligation to provide aid. The transferee countries will feel stronger and firmer in opposing political conditions as they feel it legitimate to press the issue of obligation. As indicated, some members of the OAS have already attempted to phrase the aid relationship as one of obligation; present abatement of the issue is not final. ${ }^{92}$

The International Court of Justice, although an unlikely forum, would

90 Final ACT AND Refort, supra note 9, at 21 (General Principle Eleven); id. at 44 (Annex A.IV.3). The UNCTAD language should be seen in its context. General Principle Eleven states:

International institutions and developed countries should provide an increasing net flow of international financial, technical and economic assistance to support and reinforce, by supplementing the export earnings of developing countries, the efforts made by them to accelerate their economic growth through diversification, industrialization and increase of productivity, on the basis of their national policies, plans and progranmes of economic development. Such assistance should not be subject to any political or military conditions ....

Annex A.IV.3 reads in relevant part:

The Conference considers that:

(a) Financial and technical co-operation by developed countries through both hilateral and nultilateral programmes, slould be aimed at strengthening the economic and political independence of developing countries;

(b) Financial and technical assistance to developing countries ... should supplement and facilitate the efforts of the developing countries ....

(c) Such assistance should not be subject to any political, economic, military or other conditions unacceptable to the developing countries."

91 See Finar ACT and Report supra note 9, at 21, 44, 182.

92 See text acconpanying note 67 supra. The same can be said of the 1966 Special Comm. on Principles of International Law concerning Friendly Relations and Co-operation amiong States, Report, U.N. Doc. A/6230 (1966). The report is discussed in note 143 infra. 
be a most instructive one, regardless of the context in which the issue arose. ${ }^{93}$ That court has often shown itself capable of resolving cases according to common values of various international communities. The earnest search for such common values and for the implications to be drawn from them is necessary in the present field. Results based on such common values may be appropriately labeled international law, although it is clear that the particular dispute will not formally come before lawmaking institutions..$^{94}$

Moreover, the judiciary is an important model for resolving legal disputes, partly because of its relative independence of short-term political values. More important, the judicial model, with its processes of controlling and channeling argument and its separation of legal from moral and pohtical considerations, influences dispute resolution in other arenas. These qualities can be achieved even if the International Court of Justice is not involved and if the decision is that of a United Nations forum or of an individual nation state with short-term interests in a particular outcome. Use of legal dialogue and the existence of common capacities to discriminate between good and bad arguments can thus substitute for a universally accepted lawmaker. ${ }^{95}$

${ }^{93}$ The issue might be posed to the Court by a country trying to avoid the text of an agreement in force or in the interpretation of an agreement by reference to standards that ought to govern transferor-transferee relationships. However, barriers to contentious jurisdiction might result from "domestic jurisdiction" reservations. For a list of provisions of acceptance with such reservations, see 2 S. Rosenne, THE LAw aNd Practice of THE INTERNATIONAL COURT OF JUSTICE 880-916 (1965). In such a case, a request for an advisory opinion might be made by the Economic and Social Council or the General Assembly. I.C.J. Stat. art. 65; U.N. CBARTER art. 6; G.A. Res. 89(I), 1 U.N. GAOR 176, U.N. Doc. A/64/Ad.d.1 (1947).

94 Cf. Chayes, A Common Lawyer Looks at International Law, 78 HaRv. L. Rev. 1396 (1965). See also R. FalK \& S. Mendeowitz, 2 The Strategy of Wordd Order 309-10 (1966) ; M. Kaptan \& N. KatzendacH, The Political Foundations of International Law 3-29 (1961). One consequence for international law of the greater but not unique necessity of identifying the value base of decisions has been noted in Lauterpacht's comment about the International Court: "However competent, however august, however final, and however authoritative a tribunal may be, it cannot, in conditions in which its jurisdiction is in law, and compliance with its decisions is in fact, essentially of a voluntary character, dispense with that powerful appeal to opinion which stems from the reasoned content of its pronouncements." H. Lauterpacht, The Developarent of Internattonat LaW bY tHe INTERNaTional CoURT 41 (1958).

95 Cf. M. McDodgat \& W. Burke, The Public Order of the Oceans 36-37 (1962): Despite the availability and occasional use of international offcials, most significant issues about the use of oceans are decided by the officials of nation-states [functioning in a sense as judges] who function on other occasions . . . as claimants before authority. The performance by state offcials of this double function furnishes no justification for the too common conclusion that there are no objective decisionnakers on issues concerning the law of the sea. Indeed, the very fact that the state official is on some occasions an authoritative decision-maker for world public order and on other occasions a claimant requires of the official the promise of 
III

THE IEGAI THEORY

\section{A. From Community Values to Legal Doctrine}

The use of aid values to develop aid doctrine must begin with some fundamental notions concerning "communities" and "law." The description of any community involves an attempt to discern entities which, for geographic, pohitical, economic, or other reasons, have come together in some regular pattern, and to probe the values that have brought them together. One aspect of this process is to observe how a community resolves its critical issues, thus defining itself at a given time with respect to a given issue..$^{98}$

The international aid community is a collection of nations, dominated by the richest members. It rests on an accommodation which permits the rich nations to remain very rich, relatively able to provide their people with economic, political and cultural freedom, and in relatively small danger of losing those advantages. Yet this accommodation is also significantly influenced by attitudes expressed in UNCTAD concerning the necessity of aid. In the light of those attitudes, resource sharing means either that the rich share a creative and affirmative vision of an evolving community based on such sharing or, more negatively, that the ricli are prepared to pay a price in order to maintain their present position. ${ }^{97}$ Part

reciprocity in all his decisions and claims. From this necessary reciprocity arise the recognition and a clarification of community interest which permits an appropriate compromise of competing claims and affords sanction for decision. In acting as an authorized decision-maker, the state official may accordingly be just as objective, and just as much moved by perspectives widely shared in the community of states, as a municipal decision-maker is objective and noved by perspectives in the territorial community he represents.

National decision makers have been able to sonie degree to compromise their interests in the law of the seas by their recognition of the seas as a common resource. This experience may be a helpful precedent in developing rules for the aid process. Obviously, the common ownership of the resources of the seas is easier to accept than the conmon ownership of the resources generally transferred in the aid process, which are now thought of as solely national resources. Nonetheless, I think, the comparison could be examined with profit. $C f$. Reich, Individual Rights and Social Welfare: The Emerging Legal Issues, 74 YaLE L.J. 1245 (1965).

96 Two useful sources for ideas about the interplay between the community and law are E. Ehrlich, Fundamentat Principles of the Soctology of Law 486-506 (W. Moll transl. 1936); Cairns, The Community as the Legal Order, Nomos II 25 (1959).

07 The negative approach has been put more poetically by C. P. Snow:

This disparity between the rich and the poor has been noticed. It has been noticed, most acutely and not unnaturally, by the poor. Just because they have noticed it, it won't last for long. Whatever else in the world we know survives to the year 2000 , that won't. Once the trick of getting rich is known, as it now is, the world can't survive half rich and half poor.

The Two Cultures and the Scientiric Revolution 40 (1959). 
of that vision or that price may include a firmer commitment to aid programs which do not umilaterally impose the political whims of the rich nations on the poor. ${ }^{88}$ Thus, one issue which tests and defines the aid community is that of limiting a nation's use of aid programs to achieve a unilaterally determined pohtical objective. The policy answer reached above, in discussing aid values, is that the community interest in aid precludes the burden of the pohtical condition.

The words "community imterest" can refer to the result of evaluating political alternatives and determining which one serves more preferred interests than another. The words may also indicate that a nation's choice of a particular act can only be made at the peril of destroying the kind of community of which the nation desires to remain a part.

Transferees of development aid who feel compelled to accept political

R. FaIK \& S. Mendoowtrz, supra note 94, at 12 n.10, have expressed the same idea: "The pressure for new norms, if it once is perceived as ascendant, endangers the peace of the community unless it can be satisfied." And Walt Rostow has said: "The more we examine the records of the past and the experience of the present in the adjustment to nodermity, the nuore it becomes clear that the critical moment is not when nuen begin to share the nuaterial benefits of modernization. The critical moment is when nen feel that they have become active agents in fashioning their own destiny." Rostow, The Sharing of the Good Life, 54 DeP'T State Bulc. 803, 806 (1966).

Consider also K. OLIVECrona, LAW as FACT 167-68 (1939):

In order really to gauge the influence of essentially moral feelings on the law, it is necessary to ask how far they have left their mark on the law when they have come into sharp conflict with the self-interest of those who are in power. History gives us an answer to this question. Self-interest has always been dominant. When have, e.g., the rich and powerful prompted by moral reasons introduced laws aiming at a more equal distribution of property? Never. So long as they have been able without risk to keep their wealth to themselves, they have done it. Only under pressure from below has another policy been adopted. It is true that ideahists frow the upper strata have often taken the lead in the movement for better conditions. But an appreciable result has been obtained only when the idealists have stirred the masses into action, so that the ruling class have found it advisable to buy them off with some concessions.

The question, then, is whether or not, when the pressure is strong enough, the "haves" have given and the doctrine has changed.

08 This commitunent might result from either an affirmative or a self-protective view of the stakes. The vocabulary in which the commitment was expressed might be made more meaningful and the conclusion more persuasive by taking advantage of the approaches to law problems suggested by Joln Batt's provocative article, Notes from the Penal Colony: A Jurisprudence Beyond Good and Evil, 50 IowA L. Rev. 999 (1965). The substance of that article, applied to the aid problem, might suggest that the politically "nihilist" strain anjong the poorer members of the aid comnunity was so strong, in relation to the "humanist" and more affirmatively cooperative strain, that the aid commitment slould be minimized for both practieal and theoretical legal reasons. Batt's jurisprudential premise is that much nuore sophisticated examination of the human raw nuterial than is common is essential. The premise might, if acted upon, impose impossible demands on even the most flexible lawmakers but this would need to be examined in relation to each problein posed. The substantive result in a particular conflict would of course not necessarily be different. 
conditions on aid solely because of their urgent development needs may develop attitudes of either docile disinterest or restrained resentment. Either result hampers promotion of the community of independent and interdependent nations defined in DAC and UNCTAD, because such a community cannot develop if its poor and weak members are unconcerned or rebellious. "Community interest" may, in short, express the relatively imperative character of foreign assistance, subject only to relevant conditions, in protecting the major values of community decision makers.

Any principle which is relatively imperative for protecting or developing central values of a community, can properly be developed into a legal norm. I suggest that it will be so developed when the attention of the community's lawmakers is directed to transactions dependent on the principle. The disposition to use the principle, and the way it is used, will depend on which members of the community are engaged in the lawmaking decisions.

The tradition of court-made law will tend to encourage emphasis, at least in the first instance, on more formal documentation of relatively imperative values such as constitutions, statutes, and agreements. The lack of such documents, however, may not be decisive. Legislatures and national and international officials will respond more flexibly because of their tradition of making and reacting to specific claims. But these bodies will also be influenced by formulations which take advantage of the traditions of judicial lawmaking and the kinds of demonstrations of community imperatives discussed above. ${ }^{99}$ Thus, any of these lawmaking entities could, in evaluating the data assembled above concerning the Cuba shipping restriction, conclude that the condition is illegal.

\section{B. Some International Court of Justice Precedents}

The foregoing generalizations and the documentary evidence assembled above might be conclusive in some of the contexts in which aid conditions are challenged. Their force to support the conclusions reached is also illustrated by cases in which a court's discernment of a community and its consensus is a preface to international legal norn making. The examples cited show that norm making may be based on weaker premises than those developed in this Article.

Two decisions of the International Court of Justice illustrate directly the process just described. A third recent decision of the Court suggests

99 The ideas expressed in the last four paragraphs owe a good deal to the work of Myres S. McDougal. I have made no effort, however, to conform to the McDougal vocabulary. See M. MCDOugaI \& W. BUREE, THe PUBLIC ORDER of THE OCEANS vii-xii, 1-88 (1962); McDougal, Some Basic Theoretical Concepts about International Law: A PolicyOriented Framework of Inquiry, 4 J. of CONFL. Resoc. 337 (1960). See also Fisher, Bringing Law to Bear on Governments, 74 HaRv. L. Rev. 1130 (1961). 
the added difficulty of identifying a consensus in a case involving high political tension, but it illustrates the same interplay between consensus and norm apparent in the easier cases.

The Court held in Reservations to the Convention on Genocide ${ }^{\mathbf{1 0 0}}$ that a state could remain a party to the Convention despite a reservation to which other parties objected. If the reservation was consistent with the purposes of the Convention, all parties remained bound by the Convention, although there could be no agreement between reserving and objecting parties. The Court's conclusion on this point was contrary to the international law doctrine that participation in an agreement requires the consent of all signatory parties. ${ }^{101}$

In reaching its conclusion, the Court relied on the "object and purposes" of the Convention which "imply that it was the intention of the General Assembly and of the States which adopted it that as many States as possible should participate."102 The Court decided that the objective of preventing genocide was more likely to be achieved by a weaker commitment from a larger number of nations than by a stronger commitment from a smaller number of nations, because the Convention was to some degree declaratory of an already existing standard which its advocates were seeking to universalize. ${ }^{103}$ The Court also noted some support from the growing international practice of building flexibility into a "convention of this type." 104

The evidence did not compel, although it certainly supported, the conclusion reached by the Court. The relationship between the values of the international community concerning genocide and the court's approval of one technique for implementing those values was no clearer than the relationslip between the development assistance values of the international aid community and a conclusion concerning the Cuba shipping condition. Statements of these aid values, it will be recalled, include both UNCTAD's affirmative assertion of the goals of development assistance and its exphicit rejection of political conditions on such assistance. If the International Court can properly reason from expressions of genocide values to its genocide conclusion, then an international lawmaker can properly reason from expressions of aid values to the aid conclusion suggested. ${ }^{105}$

100 [1951] I.C.J. 15.

101 Id. at 31 .

102 Id. at 24.

103 Id. at $21,23$.

104 Id. at $21-23$.

105 One might consider in this context the Court's language concerning the Genocide Convention:

In such a convention the contracting States do not have any interests of their own; they merely have, one and all. a common interest, namely, the accomplish- 
In Reparation for Injuries Suffered in the Service of the United Nations, ${ }^{100}$ the Court first decided that the United Nations Organization had a valid international claim for injury to itself when one of its agents was injured while performing services for the Organization, despite the international law principle that only states are capable of international law injury. ${ }^{107}$ The Court also decided that the Organization could espouse the claim of the individual involved, although the individual's own nation also had a right to espouse his claim. ${ }^{108}$ The Court justified this second and more radical view as follows:

To ensure the independence of the agent, and ... of the Organization itself, it is essential that ... he need not have to rely on any other protection than that of the Organization.... In particular, he should not have to rely on the protection of his own State. If he had to rely on that State, his independence might well be compromised, contrary to the principle applied by Article 100 of the Charter. ${ }^{109}$

The Court recognized that the United Nations' ability to protect its agents would permit the Organization to function more effectively. The Court preferred the values which would result in a stronger United Nations Organization.

This preference was clearly not required. An organization without the clain prerogative would be meaningful although weaker. The rationale for the preference was first, the existence of the organization; second, the implication fron that fact that the Organization should have maximun effectiveness consistent with the explicit language of its Charter; and third, the assumption that it was an appropriate function of the Court to act on this implication. The conclusion that the Organization should have rights of international clain is no more clear than the conclusion that unilateral imposition of the Cuba shipping condition disturbs the ends of the aid community. There is no doubt that the aid community exists. There is some basis for judging what contributes to its maximum effectiveness. The relationship between the aid condition and an effective aid community can be evaluated in the same way as the relationship between

ment of those high purposes which are the raison d'être of the convention. Consequently ... one cannot speak of individual advantages or disadvantages to States, or of the maintenance of a perfect contractual balance between rights and duties. The high ideals which inspired the Convention provide, by virtue of the common will of the parties, the foundation and measure of all its provisions.

Reservations to the Convention on Genocide Case, [1951] I.C.J. 23. This would be pretentious language perhaps to deal with the problem before us. But if we substitute for idealism the sense of urgency which has inspired the common aid effort and the almost umiversal concern with transfer of resources, the analogy is not remote.

106 [1949] I.C.J. 174.

107 Id. at 187 .

$108 \mathrm{Id}$. at 188.

${ }^{109} \mathrm{Id}$. at 183-84. 
the United Nations' strength and its claim prerogatives. Thus, the conclusions in the reparations and aid contexts have a similar legal character.

Finally we come to the South West Africa Cases, Second Phase. ${ }^{110}$ In that case, the Court held that it had no power, at the request of Ethiopia and Liberia, to judge that South Africa's practice of apartheid in its administration of the mandated territory of South West Africa violated the mandate from the League of Nations requiring that the territory be administered to promote the well-being of its inhabitants. ${ }^{111}$ The mandate provision nuaking justiciable "any dispute whatever" between the mandatory and "another member of the League" was interpreted to mean only disputes over special-e.g., commercial-interests of the members in the mandated territory and to exclude disputes relating to the mandatory's comphance with the general "conduct provisions" of the mandate. 112 The Court justified this conclusion on a number of grounds, ${ }^{113}$ holding primarily that bimding judicial review of the mandatory's conduct at the instance of individual nembers of the League was inconsistent with the nature of the mandate system. That system clearly contemplated that the League Council would supervise League mandates, acting according to the unanimity principles which characterized the League. It would be inconsistent with both the Council's role and the unanimity principle to make the mandatory accountable to the diverse demands of individual League inembers in a proceeding before the Court. The control of the Council had died with the League of Nations itself, and adjudication could not provide a substitute. Adequate meaning is given to the mandate language by restricting it to cases involving the League members' special interests.

Judge Jessup dissented ${ }^{114}$ stating that members of the League were always intended to have a justiciable interest in the conduct standards of the mandate. ${ }^{115}$ Jessup attacks the Court's suggestion that the notion

110 [1966] I.C.J. 6. For general and useful commentary on this case, see Dugard, The South West Africa Cases, Second Phase, 1966, 83 S. AFr. L.J. 429 (1966); Higgins, The International Court and South West Africa: The Implications of the Judgment, 42 INT'L AFr. 573 (1966); Note, 55 CAIIF. L. REv. 351 (1967).

111 The decision was by an 8-to-7 vote. The eighth vote for the majority was the second and "casting" vote of the President of the Court after his first vote had contributed to its even division.

112 [1966] I.C.J. at 28-29.

113 Id. at 29-31.

114 [1966] I.C.J. at $325-442$. In order to use the case illustratively within the ambit of this article, I have limited my comment and description to the opimion of the Court and the dissent of Judge Phillip Jessup.

115 Jessup attempts to support this view by showing with great particularity the drafting stages of the adjudication provisions of the various classes of mandate. The principal portions of the opinion relevant to this conclusion are $\$ \S \mathrm{IV}, \mathrm{V}$, and VI. Id. at $352-406$. 
of protecting such a general interest was novel, given what he calls the "motivation and operation of certain of the peace settlements of 1919 and 1920."116 In addition, Jessup argues that the Court should interpret the meaning of the well-being standard of the mandate in the light of the consensus of the 1960's, as reflected in numerous United Nation's resolutions holding that apartheid did not promote the well-being of the people of Southwest Africa.

There are two levels of consensus relevant to the South Africa Cases which might shed some light on the aid condition problem. The first concerns the nature of a member's justiciable interest under an agreement based on now obsolete attitudes and expectations and made in the context of now vanished institutional framework. The second concerns the propriety of apartheid.

There probably is no consensus on the first issue. Because the decision was a close one, however, the view of the dissent might well have become international law. That view relied on discussion surrounding the peace settlements of 1919 and 1920 suggesting that League members were intended to have a justiciable interest in the South West Africa mandate. It saw the mandate system as one in which the interests of all the participants are measured by one central element of the system, the promotion of the well-being of those whose development was labelled "a sacred trust of civilization." Therefore, it was argued, any uncertainty in the adjudication provisions should be interpreted to promote that central element. Moreover, future action within the system should be responsive to developing views of "well-being"; the mandate system should be implemented in the hight of the consensus of the 1960's concerning apartheid.

Just as one might interpret the mandate documents by reference to a context supporting a broad interest in the judicial enforcement of their standards, so one might interpret international aid arrangements by reference to the motivations and objectives in the aggregate of documents discussed above. It would then be appropriate to use those inotivations and objectives in developing legal standards for particular transactions.

The second level of consensus in the South West Africa Cases concerns the propriety of apartheid and the question whether apartheid promotes the best interests of the inhabitants of South West Africa. Despite almost unanimous agreement on this issue, there is sharp dissent by the very member of the community against whom this norm would operate.

Given the sharpness of the dissent and the resulting potential for violence, any court might hesitate to pronounce against the dissenter. Al-

116 Id. at $373-88$. 
though the decision may therefore be meaningless for norm making, it can be argued that the sharpness of the dissent in the South West Africa case puts the present case in better perspective. We noted at the outset of our discussion of "legal theory" that one of the basic elements in the definition of a community is an appreciation of the forces which create and maintain the unity of a group. ${ }^{117}$ If the forces with respect to a particular issue are significantly centrifugal, then on that issue there may be no meaningful community. Thus, it may be relevant that South Africa's international position is adamant and that that adamancy is based on the danger of domestic disruption in South Africa itself.

The dissenting transferor's interest in the aid political condition consensus operates very differently. In the first place, the aid transferor's vocabulary itself indicates that the condition discussed is bad. In contrast, it seems likely that the official vocabulary of South Africa has long since made apartheid consistent with other values which South Africa internationally espouses. In the second place, there is no doubt that the aid transferor's feehing about irrelevant, unilaterally determined, and politically exacerbative conditions is less intense than South Africa's feeling about apartheid in South West Africa. Clearly, judgments on the positions would have different domestic effects in the two situations.

The South West Africa Cases, like the Genocide and Reparations cases, shows how dependent law decisions are on the goals of the relevant community. Conflict concerning these goals only makes it clearer that the court concerned, or the law maker concerned, must understand and rationalize these conflicts. Some conflicts may be beyond judicial resolution because the grounds for choice among community purposes are too uncertain. The tenor of the premises making the aid community possible, however, is clear enough to reach conclusions on the aid condition at issue.

\section{The Analogy of Unconstitutional Conditions on Domestic Welfare Programs}

The doctrine of "unconstitutional conditions," as it is developing in the United States with reference to welfare programs, may furnish a useful analogy for an aid condition argnment. The substantive problems of the two programs are similar. Both involve economic and political problems of resource sharing and the efforts of the rich portion of the community or of the community as a whole to set the terms on which that resource sharing is to take place. Both illustrate conflicts among community values reflected in the imposition of conditions and in the grounds suggested for rejecting them.

${ }^{117}$ See text ạccompanying note 96 supra. 


\section{The "International Constitutional System"}

According to the domestic unconstitutional condition argument, the United States cannot impose on the grant of public benefits conditions which infrimge the constitutional rights of the benefit recipient, even though it is conceded that the government has no duty to provide those benefits. ${ }^{118}$ The constitutional rights of the recipient, generally of a broad and politically fundamental character and always based on the written document, override a specific community judgment concerning the limitations which should be imposed on the particular benefit.

The international unconstitutional condition argument would have to demonstrate that there are rights of the aid-transferee nations which can legitimately be called constitutional. This would not be readily conceded by all parties in interest. Despite the absence of a formal international constitutional system, however, there are raw materials for such a system and therefore for the argument based on it.

These raw materials include those already mentioned in describing the aid community: significant amounts of international resource sharing, the exphicit recognition of the necessity of effective resource sharing, and the necessity in turn of a concentrated effort on those problems impeding effective utilization of the resources shared. ${ }^{119}$ In addition, these raw materials include the international law doctrines concerning "sovereignty," "nonintervention," and the "equality of states." These doctrines, which express longstanding agreement in such disparate areas of international law as jurisdiction, state responsibility, and the use of force and war, are first premises in a system of nation-states. They remain so in the vocabulary of the United Nations Charter, the most important existing international constitutional document, ${ }^{120}$ and in the recently completed report of the United Nations 1966 Special Committee on Principles of International Law concerning Friendly Relations and Co-operation among States. ${ }^{121}$ The doctrines are part of the UNCTAD framework. In all these

118 See O'Neil, Unconstitutional Conditions: Welfare Benefits with Strings Attached, 54 CaLIF. L. REv. 443 (1966); Reich, Individual Rights and Social Welfare: The Emerging Legal Issues, 74 YaLe L.J. 1245 (1965); Reich, Midnight Welfare Searches and, the Social Security Act, 72 YaLE L.J. 1347 (1963); Note, Unconstitutional Conditions, 73 HARv. L. REv. 1595 (1960).

119 See text accompanying notes 11-69 supra.

120 The United Nations Charter provides: "The Organization is based on the principle of the sovereign equality of all its Members." U.N. CharTer art. 2, para. 1. The United Nations may not interfere with matters which are "essentially within the domestic jurisdiction of any State." Id. art. 2, para. 7. The OAS Charter provides that, "No state may use or encourage the use of coercive measures of an economic or political character in order to force the sovereign will of another State and obtain fronl it advantages of any kind." O.A.S. CBarter, art. 16. See also id. arts. 5(b), 6, 7, 8.

121 U.N. Doc. A/6230 (1966). 
contexts, the langnage of sovereignty implies limits on the powers of states to control eacli other. Set in conjunction with judgments about the role and importance of aid, they emphasize the interest of the aid community in the political independence of the transferees.

This recogmition of the relevance of the traditional concept of the nation-state is underlined by the newer view that the political independence of poor and weak nations is a goal shared by rich and poor nations. ${ }^{122}$ The relationship between economic development and political independency has been noted. ${ }^{123}$ Growing recognition of this relationship makes it a strong premise from which to draw legal conclusions. Given the materials discussed above, it is arguable that there is a constitutional system relevant to our problem whose fundamentals the aid condition breaches. Such a system would shape the arguments made by a transferee against the "improper" aid condition. An examination of the domestic unconstitutional condition doctrine will place these arguments in perspective.

\section{The Domestic Unconstitutional Condition Argument}

In the domestic context, the unconstitutional condition argument las been made in connection with claims relating to engaging in business or the professions, public employment, using public facilities-including recreational and educational facilities, and services-and, most important currently, receiving various kinds of public welfare. ${ }^{124}$

The earliest cases concerning the doctrine involved the imposition by states of himits on the freedom of foreign corporations to do business. It was held in Terral v. Burke Construction Company that a state could not require a foreigu corporation to forego use of the federal courts as a condition of doing business within the state. ${ }^{225}$ The Court in Terral decided that the interest in access to federal courts by those having meaningful contacts with more than one state was greater than the interest in permitting states to control those doing business within their borders. Earlier inconsistent conclusions ${ }^{126}$ of the Court on the same problem indicate that this result was a matter of legal-political judgment in defining the national community. The raw materials-including the constitutional right to use federal courts-which the Court used to reach its conclusion apparently consisted of the increasing mobility of business and the decreas-

122 See Packenham, Political-Development Doctrines in the American Foreign Aid Program, 18 WORID POC. 194 (1966).

123 See text accompanying notes 75-79 supra.

124 Note, Unconstitutional Conditions, 73 HaRv. L. Rev. 1595 (1960).

125257 U.S. 529 (1922).

126 Security Mut. Life Ins. Co. v. Prewitt, 202 U.S. 246 (1906); Doyle v. Continental Ins. Co., 94 U.S. 535 (1877). 
ing relevance of state lines. Those raw materials were no more accessible nor clear than the raw materials out of which aid condition arguments might be developed.

Similarly, in Frost \& Frost Trucking Company v. Railroad Commission of California, ${ }^{127}$ the Court held that a trucking company having a single private contract of general carriage could not be required as a condition of being able to continue that contract to register under a California statute which would make it a public carrier. ${ }^{128}$ The Court stated that a private carrier could not, "consistently with the due process clause of the Fourteenth Amendment," be converted into a public carrier against its will. Therefore, the question was "whether the state may bring about the same result by imposing the unconstitutional requirement as a condition precedent to the enjoyment of a privilege," which, the Court assumed for the purposes of the case before it, the state could completely withhold. It continued by emphasizing that the "surrender" of rights though in form voluntary "lacks none of the elements of compulsion" and, in language relevant to almost all development assistance relationships, observed that "the carrier is given no choice, except between the rock and the whirlpool, -an option to forego a privilege which may be vital to his hivelihood or submit to a requirement which may constitute an intolerable burden." ${ }^{129}$ The constitutional right in Frost was even less clear than the right in Terral. The interest preferred, freedom of business choice, represented a conclusion by the Court about the community's values. The Court's approach in these two cases, if applied in the context of aid conditions, would support the conclusion that the political condition on foreigu aid is unconstitutional.

While offermg less clear judicial precedent, the cases involving conditions on domestic welfare programs represent a closer factual analogy. Professor Robert M. O'Neil has pointed out the important differences between imposing conditions on a corporation doing business in a state and imposing conditions on welfare recipients. ${ }^{130}$ The business corporation can make an unemotional decision to accept the condition or go elsewhere. The welfare recipient must either accept demeaning conditions or forego essentials of life. ${ }^{131}$ O'Neil's passages clearly provoke thought on foreign assistance problems.

127271 U.S. 583 (1926).

128 Id. at 592. Holmes and Brandeis dissented, declaring that the Court was misreading the statute and it was not necessary to go beyond saying that the state could subject even a private carrier to some regulation. Id. at 600 .

$129 \mathrm{Id}$. at 593 .

130 O'Neil, supra note 118, at $443-44$. 131 Id. 
Some concrete illustrations of the constitutional strains involved in welfare condition cases may be helpful in understanding the parallels between those cases and the aid condition case. It has been argued that a minimum period of residence as a condition of welfare benefits violates a United States citizen's constitutional right to move freely in interstate commerce. ${ }^{132}$ Yet, it is certainly clear that more than a mechanical application of the commerce clause is required to reach that result. ${ }^{133}$ It is also argued that a "means" test as a condition of benefits violates a constitutional right of privacy. It is again clear that this conclusion requires some development of the nature of that "right."134

It is contended that requests for certain kinds of information in connection with the administration of welfare grants ${ }^{135}$ or a required declaration about, or renunciation of, certain future political activity ${ }^{130}$ may both violate the first amendment. This is certainly not yet accepted doctrine. Finally, the argument is made that agreements by recipients of aid for dependent children to prosecute errant fathers of the dependent children for nonsupport are invalid as are advance consents by welfare recipients to certain kinds of searches that might otherwise violate their constitutional right to privacy. ${ }^{137}$

Three points should be made about these claims, particularly those which find least support in the words or longstanding constructions of the Constitution. First, it seems clear that in dealing with these claims the courts are using values not drawn hiterally from controlling documents. The result is not any the less "law" for that reason. The rights with which the domestic doctrine deals are rooted in provisions of the Constitution, whereas the rights which the aid-transferee would assert are not part of a formal international accord. But, as the discussion of cases in the International Court of Justice indicates, once one goes beyond a document's explicit provisions, he is always relying on something more than the formally protected rights. ${ }^{138}$ There are constitutional principles beyond

132 Courts have responded to the argument with conflicting results. Compare Thompson v. Shapiro, 35 U.S.L.W. 2763 (D. Conn. June 19, 1967) (residence requirement unconstitutional), with Harrell v. District of Columbia Bd. of Comm'rs, 35 U.S.L.W. 2763 (D.D.C. June 22, 1967) (residence requirement constitutional).

133 See Harvith, The Constitutionality of Residence Tests for General and Categorical Assistance Programs, 54 CAIIF. L. REv. 567 (1966). See also, O'Neil, supra note 118, at 449. 134 See Bendich, Privacy, Poverty, and the Constitution, 54 Calm. L. Rev. 407 (1966). 135 See O'Neil, supra note 118 , at $450-51$.

136 Id. at 451 .

137 See Reich, Midnight Welfare Search and the Social Security Aet, supra note 118, at 1348-50. See also the argument that onerous provisions in most leases between an indigent tenant and a slum landlord are not in fact consensual. Schoshinski, Remedies of the Indigent Tenant-Proposal for Change, 54 GEo. L.J. 519, 552-57 (1966).

138 See text accompanying notes 100-05. 
constitutions and there may be international constitutional principles not dependent on formal sources. ${ }^{139}$ The "freedom of interstate movement" principle, as reflected in the reasoning cited above, is an example of such a principle. The argument for this freedom, as developed by Professor Harvith, rests on a notion of community which is superior to the welfare administration judgments of either the states or Congress.

Second, as we have noted before, adjudication often involves the adjustment of conflicts between a community's general and particular values. The welfare examples require weighing a specific condition against the more general values of the welfare program and of constitutional protection. The same kind of conflict is involved in weighing the Cuba shipping restriction against the more general values of the international aid programs.

Third, the welfare cases are instructive in isolating the community values specially served by welfare programs and in showing how those values are impaired by imposing conditions which are irrelevant or which infringe other claims of particular importance to welfare recipients. Some of the problems incident to being a receiver of benefits may be the same for both the domestic and international cases. Legal doctrine used to resolve those problems in domestic welfare cases will rest ultimately on factual assumptions or findings no more formal or consciously law-creating than those of UNCTAD. In each case, the assumptions concern the interdependence of the community involved, the destructiveness of certain kinds of conditions, and the necessity of respect for the "personality" of the recipient.

Professor O'Neil does not conclude that all welfare conditions are constitutionally invalid but suggests a framework for deciding whether particular conditions are unconstitutional. His analysis requires balancing three elements present in all unconstitutional condition cases: the benefit, the condition, and the interest infringed. For this purpose O'Neil proposes some specific questions, the following of whicl are of special relevance in the aid context: (1) Could the object of the condition be achieved directly? (2) How relevant is the condition to the benefit? (3) What alternatives, if any, would achieve the same end? (4) How important is the result to the individual recipient? (5) How does the condition influence the beneficiary's judgment? (6) In what form is the condition imposed? (7) What procedures are provided for determining a breach of condition ? $^{140}$

130 Cf. Miller, Notes on the Concept of the "Living" Constitution, 31 GEo. WaSH. L. REv. 881 (1963).

140 O'Neil, supra note 118 , at $460-77$. 


\section{Application of the O'Neil Analysis to Aid Conditions}

(a) Could the Object of the Condition be Achieved Directly?-The United States could not impose its own attitude toward Cuba on the governnient of another nation without force or some other kind of economic coercion, although it could attempt persuasion. Assuming that some kinds of economic coercion are not proscribed by international law, ${ }^{141}$ it might be argued that coercive aid conditions are permitted. Where such coercion threatens development assistance, however, doctrines permitting economic coercion may have to be changed to reflect the international consensus on economic interdependence and the essentiality of aid.

Moreover, the "law" rules for development assistance conditions must respond not only to the imperatives of economic development but also to issues concerning the political prerogatives of states, particularly economically weak states, many of which are also newly independent. There is, in short, an interplay between economic development and what has been called "political development."142 The economic development side lias been discussed. The political development side of this interplay may impose limits on one state's unilateral interference with development in other states. The inherited and newly-developing attitudes concerning the prerogatives of independence and sovereignty are relevant to the issue of political development. ${ }^{143}$

141 Economic coercion against nations may be permissible. I D. O'CoNNELL, INTERNatronal LAw 328 (1965). However, in addition to the considerations in the text, one might rely on the documents cited in notes 120-21 supra.

142 See Packenham, supra note 122, at 194.

143 The identification of the prerogatives of independence and sovereignty when seen as relevant to development assistance problems may pose serious analytical difficulties. For example, one might consider the relevance of protecting "sovereignty" when the entity having formal independence, and therefore sovereignty as traditionally thought of, is for a variety of reasons an artificial or unstable entity. See Kapil, On the Confict Potential of Inherited Boundaries in Africa, 18 WORLD PoL. 656 (1966). This complex problem has an important bearing in responding to our adopted O'Neil question and is not without parallels in the domestic problems which ONeil is addressing.

Some of the crosscurrents relevant to this problem may he seen in operation in 1966 Special Comm. on Principles of International Law concerning Friendly Relations among States, Report, UN. Doc. A/6230 (1966). Attitudes toward aid conditions and economic coercion were certainly implied in the Committee's effort to explicate the principles concerning "the duty not to intervene in matters within the domestic jurisdiction of any state, in accordance with the Charter." Id. at 124-25. The Committee was also concerned with "the principle of the sovereign equality of States," id. at 176; "the duty of states to co-operate with one another in accordance with the Charter" ineluding discussions of "[t]he legal nature of the duty to co-operate," $i d$. at 191; and "[c]o-operation in economic and trade matters and assistance to developing countries," id. at 194. Even the United States jomed in proposing a formulation which, though falling short of any affirmative ald duty, still recognizes the impact of its economic policies on the effective growth of developing countries. See $i d$. at 184-85. During the discussions of various proposals before the Committec, there was talk concerning the "community interest" involved in development 
(b) How Relevant is the Condition to the Benefit?-We have indicated above that the political condition is not relevant, but is in fact harmful to the achievement of aid values. Even the "testimony" of the United States is, on balance, against the substantive aid value of the condition to aid.

(c) What Alternative Means, If Any, Would Achieve the Same End?Alternative means to achieve the end which the condition is designed to achieve may, hike persuasion or other kinds of economic coercion, be less effective or, like force, may be more explicitly proscribed. However, persuasion is clearly more consistent with international values which, we lave noted, may have priority claims to protection.

(d) How Important is the Result to the Individual Recipient?-The discussion in Part I indicates that the benefit is essential to the well-being of the recipient and may be essential to its survival. The legal norm can be stated on the assumption that this is so.

(e) How Does the Condition Influence the Beneficiary's judgment?The condition is explicitly intended to affect the beneficiary's judgment and is likely to do so. Significantly, the Britisl and French ignored the Cuba shipping provision, and Britain reportedly reacted "more in sadness than in anger" that the historically important aid relationship with the United States should end on so small an issue. ${ }^{144}$ Their reaction to this shipping issue and to the later North Vietnain shipping issue ${ }^{145}$ suggests clearly both the unilateral character of the United States judgment involved and its coercive effect with respect to small and poor nations. $\mathrm{Ob}-$ viously, a poor nation could not afford to express its reaction so explicitly. (f) In What Form is the Condition Imposed?-The condition is used as a lever in bargaining over an essential need of the recipient. This is not a context in which consent can be taken at face value..$^{146}$

(g) What Procedures are Provided for Determining a Breach of Condition? - The United States determines unilaterally whether the condition has been breached, although clearly it is responsive to diplomatic pressures from those recipients in danger of losing the proffered benefit.

assistance and the legal nature of the duty to cooperate. Id. at 191-92. Although no conclusion was reached, the drift is clear. Id. at $247-48$. The principal problem remaining is an intellectual ordering of some historically separate concepts into an increasingly compelling and widespread consensus on values. For a relevant discussion in reference to forms of intervention, see $i d$. at $138-40$.

144 Washington Post, Feb. 20, 1964, $\S$ A, at 15, col. 1, reprinted in 110 CoNG. REc. 3333-34 (daily ed. Feb. 21, 1964) (inserted at the request of Senator McGovern).

145112 CoNG. REc. 15309 (daily ed. July 18, 1966) (table of flagships in North Vietnamese ports inserted at the request of Senator Harris).

146 Cf. Reich, Midnight Welfare Search and the. Social Security Act, supra note 118, at $1348-50$. 
These tests do not all run in one direction. It is doubtful whether a similar list compiled in conjunction with judicial testing of conditioned domestic welfare would indicate a trend in one direction. Nevertheless, if similar facts were present in a domestic context, the Supreme Court of the United States would have ample material from which to formulate law, and its pronouncement would be accepted as law, despite the presence of apparent and substantial "political" elements. I see no fundamental difference between such cases and the aid condition issue. In short, domestic unconstitutional condition cases, like the International Court of Justice cases, suggest a basis for law norms applicable to aid conditions. In addition, the domestic cases provide a useful framework for evaluating particular conditions.

The United States might well concede that the Cuba shipping restriction is not aid-relevant, yet still argue that it has the right to impose this condition. Under the United States view of the world crisis the shipping restrictions are part of a process of containing "communism"; ${ }^{147}$ the spread of communism would be inimical to a variety of interests which the United States shares with others. The problem is the juxtaposition of the United States policy on this issue with its willingness to provide assistance.

At this point we are not assuming that the United States must provide assistance. ${ }^{148} \mathrm{~A}$ reasonable condition imposed by a voluntary transferor should be permissible. But this begs the precise question involved in the unconstitutional condition and the International Court of Justice cases. The United States as a domestic welfare transferor has two minds concerning the purposes of domestic welfare policy, but legal analysis can resolve its effort to accomplish two contradictory policies at once. The development of an international response to the United States' ambivalence about the ends of development aid presents a similar legal issue.

147 See 22 U.S.C. § 2151 (Supp. II, 1966).

148 Consider, however, the draft recommendation submitted by twelve underdeveloped nations to the Third Committee of UNCTAD: The rapportent states that the sponsors considered that "the developed countries should feel it an obligation to provide the resources needed to meet the existing and growing trade gap of developing countries." FINAI ACr AND REPORT, supra note 9, at 176. Consider also the implications of the Reich argument concerning entitlement: "The idea of entitlement is simply that when individuals have insufficient resources to live under conditions of health and decency, society has obligations to provide support, and the individual is entitled to that support as of right." Reich, Individual Rights and Social Welfare: The Emerging Legal Issues, stipra note 118, at 1255-56. Most of the reasons for supporting a principle of "entitlement" in respect of domestic welfare programs analogously support international "entitlement." It is true that the former situation involves an individual operating within a formalized community while the latter concerns a State operating in a less fornal commumity. In each case, however, the core problem is clearly that of discerning the commumity. 
The competing values in the international context which will shape this response are not formally codified, but they are clearly discernible.

\section{CONCLUSTON}

As this article has indicated, substantial resource transfers are made to promote development, and there is some consensus concerning the shared interests of transferors and transferees in such transfers. It is suggested that this consensus precludes, for legal reasons, the imposition of transfer conditions which are at once irrelevant to development, unilaterally determined, and pohtically exacerbative. Elimination of such conditions is essential to the preservation of the proclaimed common interests of the nations involved in aid transfers. Moreover, the conclusion may be reached within the framework of lawmaking as shown in illustrative cases in the International Court of Justice and in the particularly relevant example of domestic welfare conditions in the United States. Such examples, moreover, will hopefully be persuasive of the possibility of developing legal principles to govern other development assistance relationships. At least they should be helpful in sharpening the dialogue concerning the relation between aid and aid conditions. 